\title{
Entrepreneurship and Economic Performance in Africa: A Sectoral Analysis with Focus on the Role of Finance, Institutions and Globalization
}

\author{
John Bosco Nnyanzi ${ }^{1}$, Bruno L. Yawe ${ }^{1} \&$ John Ddumba-Ssentamu ${ }^{1}$ \\ ${ }^{1}$ Department of Economic Theory and Analysis, School of Economics, Makerere University, Kampala, Uganda \\ Correspondence: John Bosco Nnyanzi, Department of Economic Theory and Analysis, School of Economics, \\ Makerere University, P.O Box 7062, Kampala, Uganda. E-mail: jbnnyanzi@yahoo.com
}

Received: October 28, 2018

Accepted: November 14, 2018

Online Published: December 5, 2018

doi:10.5539/ijef.v11n1p37

URL: https://doi.org/10.5539/ijef.v11n1p37

\begin{abstract}
The main aim of the paper was to investigate the role of entrepreneurship on economic performance but with focus on sector-wide growth in 12 selected African countries during the period 2006-2016. Overall, the results suggest that while the quantitative impact of entrepreneurship on economic growth is positively significant, there is a differential effect on the sectors. The service sector in particular is associated positively with entrepreneurship whereas there is no evidence in the data that the growth in the manufacturing and agriculture sectors is influenced by entrepreneurship activities. A further analysis that includes interactions in the model supports the conditionality hypothesis that globalization as well as the quality of institutions and financial development matter in the entrepreneurship-growth nexus. In addition, while internet access and government consumption appear beneficial for the manufacturing and service sectors, the role of personal remittances is observed important for the agriculture sector contribution to GDP whereas trade in services matters for each sector but most significantly in the latter sector. In light of the findings policy recommendations are suggested.
\end{abstract}

Keywords: entrepreneurship, sector-wide GDP, globalization, finance, political stability

\section{Introduction}

Entrepreneurship is generally believed to be a critical part of economic growth and economic development. Although tremendous effort has been done to examine the empirical relationship between these variables, the extent to which entrepreneurship affects individual sectors of the economy is still unknown. A notable theoretical fact however is that entrepreneurship is important for the continued dynamism of the sectoral growth of the modern economy. Given the heterogeneity of sectors, the entrepreneurial effect on aggregate GDP may not adequately explain what happens when individual sectors are considered. Certainly there are observed variations in the rate of growth of GDP on the one hand and sectoral growth on the other. The African economies in particular have for the last two decades till 2016 recorded remarkable performance in terms of economic growth. Nevertheless, in 2016, the overall GDP growth performance declined drastically, dropping to 1.7 per cent, lower than the developing country average of 3.8 per cent (Economic Commission for Africa [ECA], 2017). On the other hand, sectoral growth is not uniform. For example, industrial growth has fallen behind GDP growth in SSA since 1980, making the continent less industrialized today than it was four decades ago. According to ECA (2017), the contribution of Africa's manufacturing sector to the continent's gross domestic product declined from $12 \%$ in 1980 to $11 \%$ in 2013 , where it has remained stagnant over the past few years. In fact, between 2010 and 2014, the growth in Africa's manufacturing sector has been recorded as low as at $4.3 \%$ a year. On its part, the services sector has witnessed consistent increase in its share of GDP. For example, during the period 2010-2014, the sector generated 48\% of Africa's GDP growth, up from $44 \%$ in the preceding decade. The sector contributed about $47 \%$ of growth in Sub-Saharan Africa over the period 2000-2005, compared to 37\% and $16 \%$ from industry and agriculture respectively. A number of factors to explain the observed trend are less clear but the debate points to the extent of economic growth abroad and commodity prices as well as economic and political environment, nature of institutions, infrastructure status, and, financial development. On the other hand, entrepreneurship could contribute to economic performance by introducing innovation, creating change, creating competition and enhancing rivalry, though it is equally not uncommon to find it related to individual sectors of the economy such as education (von Graevenitza et al., 2010), health (Shepherd \& Patzelt, 2015) and the 
infrastructure sector (Uchehara, 2016).

In the current study, we investigate the role of entrepreneurship on economic performance but with focus on sector-wide growth. The rationale of the analysis hinges on the fact that whereas entrepreneurship appears to have attracted less attention as a factor likely to engineer growth in developing countries, entrepreneurship, with its focus on opportunities, is often seen as one of the cornerstones of poverty alleviation and economic growth in sub-Saharan Africa (Omoruyi et al., 2017). It suffices here to note that according to the World Bank, the number of people living in extreme poverty - those who live on $\$ 1.90$ a day or less - is on the rise in Sub-Saharan Africa, comprising more than half of the extreme poor in 2015. Entrepreneurship could be a panacea to the status quo and thereby improve economic performance. Besides, theory is unequivocal in its support of the hypothesis of the entrepreneurship-growth nexus. For example, right from the seminal works by Schumpeter (1912, 1934, 1942 ) to the modern day economics of innovation, entrepreneurs are assumed to play a key role in the economic development of a country via raising productivity through technical and other forms of innovations, commercializing new inventions and products, restructuring and transformation of economy, making markets more competitive and thereby reduce both static and dynamic market inefficiencies, stimulating a redistribution of wealth, income and political power within societies in ways that are economically positive and without being politically disruptive, and, finally improving the social welfare of a country by harnessing dormant, previously overlooked talent. In so doing, entrepreneurs are likely to spark economic development by inter alia starting new businesses, creating jobs, and contributing to improvement in various key goals such as GDP, exports, standard of living, skills development and community development. Contextually, by introducing innovation, creating change, creating competition and enhancing rivalry, entrepreneurship would qualify to be an engine of growth. On the contrary however, even though innovations create the new opportunities, radical or 'disruptive' innovations could plunge industries into a higher risk (Rae, 2007). The turbulence effect of entrepreneurship on economic growth that pertains to entry and exist is likely to affect growth negatively, although empirical work appear to suggest that the relevant effect might be minimal in the short run (Bathelt, 2001) but significant in the long run especially in service industry than in manufacturing industry (Chang, 2011). The unresolved empirical puzzle however is the extent to which entrepreneurship could quantitatively influence growth of individual sectors that contribute to the aggregate growth. The main sectors, viz., primary, secondary and tertiary sectors, deserve attention as they are likely to determine the extent of poverty reduction on account of the employment base they command. Could the level of entrepreneurship in Africa whether directly or indirectly explain the performance of the main sectors of the economy? And if so, to which extent and which channels primarily matter? It is the purpose of the current study to provide evidence-based responses to these empirical questions in order to inform policy.

Certainly the empirical arena is not short of evidence in support of theory associating entrepreneurship to economic performance and development albeit only at aggregate level (see Henrekson, 2002; Carree \& Thurik, 2003; Audretsch et al., 2006; and Fritsch, 2013, for a summary of these studies). Essentially we identify three divergent findings from the existing literature. While the first category reports a positive and significant effect of entrepreneurship on economic growth (e.g. Raoofi et al., 2014; van Stel et al., 2004, 2005; Audretsch et al., 2006, for Germany; Koo \& Kim, 2009), the second school of thought documents a negative relationship between entrepreneurship and growth (e.g. Salgado-Banda (2005) for OECD countries; Carree et al. (2002). Still there are studies that instead report insignificant results (e.g. Wong et al., 2005). Yet other scholars find that the effect depends on the country's level of per capita income (e.g. van Stel et al., 2005), human capital (e.g. Rodrigues, 2018) or institutions (Eklund \& Sund, 2014). Despite these numerous studies linking entrepreneurship to economic growth the issue is yet to be fully resolved. The void may be attributable to the observation that none of the studies has gone beyond the aggregate level of economic activity in their analysis. Yet the risks involved in aggregating growth, thereby assuming homogeneity of sectors, have been known to researchers for some time (Scott, 1986). On the other hand, the basis of conflict in the findings would be methodological and sample-related. For example, a variety of the existing studies have ignored heterogeneity issues despite the well-known econometric risks involved in doing so. Similarly, as explicit in most of these studies, focus has mainly been on the developed countries or a mixture of both advanced and developing countries. It is not illogical to consider such an approach inappropriate especially given the fundamental differences in terms of economic development and regional characteristics. Moreover, the resultant policies from a study done on a sample drawn from developed economies may not necessarily be relevant to developing countries although the opposite may neither be indismissible.

The purpose of the current paper is analyze entrepreneurship effects on sectoral growth with focus on selected African countries. Although there is scanty empirical coverage of the topic, we identify a few exceptional studies 
that have taken a sectoral approach similar to ours. One closely related study by Herrington and Kelley (2013) posits that most entrepreneurial activities are developed in mining and the agricultural sectors and that the lack of well-developed industry has an inverse effect on economic growth in Africa. In the current study, however, we extend the study to more than one country in order to enjoy the well-known advantages of panel data over time series in analyzing such issues. We focus on analyzing entrepreneurial effects on the primary, the secondary and the tertiary sectors of the economy, respectively represented by agriculture, manufacturing and services sectors. The main advantage of following a sector-specific approach is the level of detail with respect to the entrepreneurial influence on the individual components of GDP growth for relevant policy formulation and implementation.

The basis for focusing on Africa is evidence-driven. For example, as earlier noted in Elkan (1988), there is a widespread belief that indigenous entrepreneurship is less well represented in African countries than in other parts of the developing world. According to 2018 Global Entrepreneurship Index (GEI) by Acs et al. (2017), while the world scores improved by $3 \%$ on average in 2017, Africa still lags behind the rest of the world despite a few signs of improvement. For example, the index reports that while the Middle East and North Africa region demonstrated strength in product innovation and risk capital, Sub-Saharan Africa has the greatest strength in opportunity perception and demonstrated an improvement by $1.5 \%$ on average over the previous year's GEI score, with Botswana and South Africa leading the way. It is nevertheless observed that the region performs poorly in terms of Startup Skills, Risk Acceptance and Risk Capital, partially reflecting the need to improve access to education and skills that support careers in entrepreneurship, making the general risk climate favorable and capital available. The rest of Africa still faces entrepreneur challenges in line with competition where there are still large barriers to entry for new firms. Entrepreneurship is nevertheless viewed as a possible solution to the stubborn income gaps resulting from a mismatch between macroeconomic growth as well as per-capita GDPs on the one hand, and the everyday livelihoods of Africans on the other (Fal, 2013). Table 1 presents a summary of the trend in entrepreneurship relative to sector-wide growth in Africa. Pronouncedly notable from the table is that while the new business density in SSA increased from 1.6 in 2006 to 3.2 in 2016, the shares in GDP of the manufacturing, agriculture, and service sectors reduced from $11.6 \%, 19 \%$, and $57 \%$ to $10 \%, 16.2 \%$ and $53.9 \%$ respectively, reflecting a reduction of $2.3,1.6$ and 3.1 percentage points. Similarly, annual GDP growth witnessed a reduction from 7\% in 2006 to $1.3 \%$ in 2016, and the annual GDP per capita jumping from $4.1 \%$ in 2006 to $-1.4 \%$ in 2016. We can compare these trends to those in the East Asia and Pacific countries where the reductions were far lower than those in SSA almost in each sector. Specifically, we observe a decrease from $25.3 \%$ in 2006 to $23.2 \%$ in 2016 in the manufacturing sector; $6 \%$ in 2006 to $5.1 \%$ in 2016 for the agriculture sector; and, $55.5 \%$ in 2006 to $59.6 \%$ in 2016 for the service sector. Whereas the new business density in the region increased from 4.4 to 6.6, there was comparatively low reduction in the annual GDP growth rate from $5.5 \%$ to $4.1 \%$ in the respective years and annual GDP per capita dropped from $4.8 \%$ in 2006 to $3.4 \%$ in 2016. According to Leke \& Barton (2016), the same year 2016 witnessed the number of countries whose growth was similar or quickening halving to 13 - Botswana, Cameroon, Côte d'Ivoire, the Democratic Republic of Congo, Ethiopia, Gabon, Ghana, Kenya, Madagascar, Namibia, Senegal, Tanzania and Zimbabwe. Additionally, Africa's six largest economies experienced slowing growth, partly reflecting lower resource prices and the Arab Spring.

Table 1. New business density (new registrations per 1,000 people ages 15-64), GDP and Sectoral shares for 2006 and 2016

\begin{tabular}{|c|c|c|c|c|c|c|c|}
\hline & $\begin{array}{c}\text { AGRIC } \\
(\% \text { of GDP) }\end{array}$ & $\begin{array}{c}\text { MAN } \\
\text { (\% of GDP) }\end{array}$ & $\begin{array}{c}\text { IND } \\
(\% \text { of GDP })\end{array}$ & $\begin{array}{c}\text { SERV } \\
\text { (\% of GDP) }\end{array}$ & $\begin{array}{l}\text { GDPPC growth } \\
\text { (annual \%) }\end{array}$ & $\begin{array}{c}\text { GDP growth } \\
\text { (annual \%) }\end{array}$ & $\begin{array}{c}\text { New business } \\
\text { density }\end{array}$ \\
\hline & \multicolumn{7}{|c|}{2006} \\
\hline Sample & 18.1 & 11 & 25.6 & 52.8 & 4.9 & 6.8 & 2.9 \\
\hline East Asia \& Pacific & 6 & 25.3 & 37.1 & 55.5 & 4.8 & 5.5 & 4.4 \\
\hline Middle East \& North Africa & 5.4 & 11.8 & 52.1 & . & 3.8 & 6 & 3.4 \\
\hline OECD members & 1.5 & 15.3 & 24.6 & 67.5 & 2.2 & 2.9 & 5 \\
\hline Small states & 3 & 11.7 & 58.4 & . & 7.9 & 10.1 & 5.4 \\
\hline \multirow{2}{*}{ Sub-Saharan Africa } & 19 & 11.6 & 28.2 & 57 & 4.1 & 7 & 1.6 \\
\hline & \multicolumn{7}{|c|}{2016} \\
\hline Sample & 16.6 & 9.3 & 21.4 & 53.5 & 1.2 & 3.1 & 5 \\
\hline East Asia \& Pacific & 5.1 & 23.2 & 33.6 & 59.6 & 3.4 & 4.1 & 6.6 \\
\hline Middle East \& North Africa & 5.4 & 11.1 & 37.2 & 54.2 & 2.8 & 4.6 & 7.3 \\
\hline OECD members & 1.4 & 14.3 & 22.5 & 69.7 & 1.1 & 1.7 & 6.3 \\
\hline Small states & 2.5 & 10 & 35.6 & 56.6 & -0.2 & 1.6 & 7.1 \\
\hline Sub-Saharan Africa & 16.2 & 10 & 22.5 & 53.9 & -1.4 & 1.3 & 3.2 \\
\hline
\end{tabular}

Note. New businesses registered are the number of new limited liability corporations registered in the calendar year; AGRIC is agriculture; MAN is manufacturing (including construction); SER is service; GDPPC is GDP per capita. Source: World Bank. 
In light of the above stylized facts, the logical question as to whether there is an association between the observed trend in entrepreneurship and sector-wide performance is not only relevant but also fundamental. Certainly we are aware of the potential impact of the environment in which entrepreneurship might operate to produce influence, if any, on sectoral growth. Therefore to further understand the dynamics of the purported relationship in question, and to differ from the previous literature that treats entrepreneurship impact on GDP growth in isolation, we examine the interaction effects of entrepreneurship on growth. The selected interactions for the study include institutional quality, financial development and globalization. Although some studies (e.g. Smith, 2010) fail to find evidence in support of the hypothesis that the entrepreneurship effect on growth is dependent on other factors such as labor, capital, knowledge or on the presence or absence of market friendly government policies, and therefore emphasizing its independence in driving economic growth, we are not aware of any study that has tested the hypothesis on sectoral data sets. Moreover the motivation behind checking for these interactions hinges on several economic justifications. Lundin (2015) for example argues that regulatory obstacles to setting up a new firm costly licenses and other stringent requirements for market entries can prevent entrepreneurs to quickly react to new business and innovation opportunities, and would therefore discourage entrepreneurship. Also, it is also not inconceivable that without good macroeconomic stability, entrepreneurship would adversely effect growth. Accordingly, preliminary empirical evidence suggests that the effect of entrepreneurial activity is strongly moderated by other factors such as the institutional quality (e.g. Bruns et al., 2015), culture (e.g. Linan \& Fernandez-Serrano, 2014) or property rights (e.g. Nyström, 2007). By implication, it is highly likely that the marginal effect of entrepreneurship on growth could differ across regions and countries depending on the institutional environment. Other empirical works by inter alia Akpor-Robaro (2012), Vinig and Kluijver (2007) appear to augment the interaction hypothesis as they suggest the globalization phenomenon is associated with entrepreneurship development in developing economies, making the former's influence in the entrepreneurship-growth nexus an inevitable possibility. Similarly, we are sensitive to the generally accepted view that entrepreneurs require credit to engage in innovations and start-ups, and hence a likelihood that their role in sector-wide growth would hinge on the financial environment. Perhaps one would be interested in understanding whether the effect of entrepreneurship would differ depending on the level of economic development. Already, support for this hypothesis can be found in studies such as van Stel et al. (2005). Relatedly, we endeavor to provide empirical evidence on the same.

The findings from the current investigation are likely to benefit relevant policy formulation. Specifically for SSA, the need for evidence-driven policies as well as the relevant literature in the field cannot be overemphasized, hence making the current study timely. A recognition that entrepreneurship is crucial to a dynamic economy calls for detailed studies that are currently scanty in Africa in quantitatively articulating the implications for growth both at aggregate and sectoral levels. There is hope that the current study bridges this gap within the given caveats.

Overall, the results based on 12 African countries, viz., Botswana, Congo, Dem. Rep., Lesotho, Mauritius, Morocco, Namibia, Nigeria, Rwanda, Senegal, Sierra Leone, South Africa and Togo, suggest that while the quantitative impact of entrepreneurship on economic growth is positively significant, there is a differential effect on the sectors. The service sector in particular is associated positively with entrepreneurship whereas there is no evidence in the data that the growth in the manufacturing and agriculture sectors is influenced by entrepreneurship activities. A further analysis that includes interactions in the model supports the conditionality hypothesis that globalization as well as the quality of institutions and financial development matter in the entrepreneurship-growth nexus.

The rest of the paper is organized as follows. While the next Section 2 presents an overview of literature, in Section 3 we present the empirical strategy, estimation and data, while in Sections 4 and 5 are the results, and, summary and concluding remarks respectively.

\section{Overview of Literature}

Admittedly, there exists plenty of literature both theoretical and empirical that relates entrepreneurship and economic growth albeit with varying results. On the theoretical front, we can identify inter alia two theories that stand out in explaining entrepreneurship in relation to growth and development: the Schumpeterian theory (Schumpeter, 1911) and the recent endogenous theory. The former states that entrepreneurship encourages an innovation process that affects development. In The Theory of Economic Development, Schumpeter (1904) emphasizes the role of the entrepreneur as prime cause of economic development via the entrepreneur's challenge to the incumbent firms through introducing new inventions that make current technologies and products obsolete. For Schumpeter, this process of creative destruction shapes the economy in the positive direction of development. Support for this theory can be found in later empirical studies by inter alia Aubrey et 
al. (2015), Low and Isserman (2015), Bosma et al. (2011), Bjørnskov and Foss (2016), and, van Stel et al. (2005). On the other hand, the modern empirics follow the endogenous growth models that incorporate entrepreneurship as endogenous, as opposed to previous classical models by say Solow (1956) where the growth rate is completely determined by advances in knowledge or the technological progress. In the endogenous theory, knowledge is modeled as being endogenous where growth is generated by investments in knowledge and the models outline the determinants in investment decisions in knowledge (Bunyasrie, 2010). However, as the latter author argues, it was not common for endogenous growth models to explicitly address the issue of entrepreneurship as a driving force of technological and economic development until later studies such as the likes of Aghion and Howitt (1992), who contributed to the endogenous growth literature by including the entrepreneur through connecting purposive, profit-seeking investment in knowledge to the persons performing this task, and in so doing, pragmatized the Schumpeterian theoretical link between the Entrepreneurship and economic development.

The empirical analysis draws from the aforementioned theoretical basis to relate the relationship between entrepreneurship and economic growth albeit with consequent mixed results (Stam, 2008). The various indicators of entrepreneurship including the sum of entry and exit in industries, the size distribution of entrepreneurs in regions, the number of market participants in an industry, and of the number of self-employed, have been partly to blame for the observed inconsistencies in the findings (Carree \& Thurick, 2002). The divergences could also be attributed to the data type used, particular country or countries or regions under analysis as well as methodological differences. In the context of the data, Raoofi et al. (2014) use the Global Entrepreneurial Monitor (GEM) and the World Bank datasets to examine the relationship between entrepreneurship and economic growth in fifty selected countries during the period 2004 and 2012. The results indicate that entrepreneurship has positive and significant effect on economic growth, just as it is the case for the rate of enrollment in schools and trade liberty while the proportion of government expenditure to Gross Domestic Production is found to adversely affect growth. Similar findings of the positive role of entrepreneurship on growth based on the same dataset can be found in other studies (e.g. van Stel et al., 2005; Audretsch et al., 2006; Koo \& Kim, 2009; Stam \& van Stel, 2009; Urbano \& Aparício, 2016). Some others too (e.g. Smith, 2010) that use alternative datasets however equally document positive relationship.

On their part, Wennekers et al. (2005) estimate three specifications linking entrepreneurship and per capita income, viz., a linear relation, an inverse, and a squared specification with 2SLS and internal instruments, using GEM data for entrepreneurship in 36 countries, while controlling for business cycles and economic institutions. The results suggest that there exist a nonlinear relationship between the degree of entrepreneurship and per capita income. A similar result can be found in Nyström (2007) but here the estimation based on the OLS and 2SLS with internal instruments as a test for robustness show that the non-linear result found between entrepreneurship and economic growth is conditional on protection of property rights. A similar study by Valliere and Peterson (2009) focuses on 44 countries between 2004 and 2006 to examine both the direct as well as the indirect effect of the GEM measure of entrepreneurship on economic growth, while controlling for macroeconomic factors. The indirect effect is captured by interacting entrepreneurship with economic components. The results from OLS estimation, show that while in developed countries a significant portion of economic growth can be attributed to entrepreneurs, there is no evidence in the data to suggest any entrepreneurial effect for developing countries.

On the other hand, a study by Salgado-Banda (2005) who use self-employment as a measure of entrepreneurship with focus on the 22 OECD countries, report a negative relationship between the variable and economic growth. Support for the negative relationship between entrepreneurship can also be found in Blanchflower (2000) after controlling for age, education and gender, in the model. The author employs the two-way fixed effects approach to estimate an ML (Maximum likelihood) probit model that includes a lagged dependent variable as an explanatory variable. In his case, too, data is collected from the 23 OECD countries between 1966 and 1996, but divided into ten year periods. Similar findings are reported elsewhere (e.g. Salgado-Banda, 2005, for OECD countries; and Carree et al., 2002). The latter in particular analyze GEM-entrepreneurship effect on inclusive, under a VECM framework, to record an existence of both longrun and short-run relationships between entrepreneurship and inclusive growth in 23 OECD countries in the period 1976-1996. On their part, van Stel at al. (2005) use another dataset, the Total Entrepreneurial Activity (TEA), in examining the influence of entrepreneurship on GDP growth for 36 countries in addition to testing whether any observed influence depends upon the level of economic development. The main outcome is that entrepreneurial activity affects economic growth, but that this effect depends upon the level of per capita income.

Likewise Rodriges (2018) analyzes the impact of the opportunity and necessity entrepreneurship on economic 
growth taking human capital as mediating factor in the relation. The results obtained using the fixed effects panel data estimations on OECD and non-OECD countries, over the period 1990-2016 suggest that while total entrepreneurship has a positive impact on economic growth, distinguishing between the types of entrepreneurship provides clear evidence that opportunity entrepreneurship fosters economic growth, whereas necessity entrepreneurship inhibits it. However, human capital is found to mitigate the negative impact of necessity entrepreneurship whereas in the case of opportunity entrepreneurship, the direct positive impact observed is reduced as human capital increases.

As noted earlier, sectoral studies in the field are scarce. Exceptions such as Yu (1998) who discuss the role of entrepreneurship in the manufacturing sector and the economic development of Hong Kong record a positive association among the variables. A later study by Chenaa and Kimengsi, (2016) that investigates the role of agriculture, industry and FDI economic growth of Cameroon between 1975 and 2014, using the Ordinary Least Squares (OLS), find that the relevant coefficient in each model is positive and statistically significant, further cementing the hypothesized entrepreneurship-growth nexus.

Overall, the existing empirics exhibit conflicting findings, which as alluded to earlier could be explained by the differences in datasets used, countries or regions analyzed and methodologies applied. Studies on Africa are notably very limited but more so, focus has generally been on the aggregate growth. The current paper takes a different approach by concentrating on sector-wide GDP but without sidelining aggregate GDP in order to provide a detailed analysis of the contribution of entrepreneurship to economic performance. Again, an attempt is made to examine the influence of the presence globalization, financial development and institutions on the observed relationship between entrepreneurship and sector-wide growth. The rationale for including these interactions has earlier on been advanced.

\section{Empirical Strategy, Estimation and Data}

\subsection{Empirical Strategy}

The aim of our study is to measure the contribution of entrepreneurship to sector-wide GDP growth and establish whether the consequent contribution, if any, is moderated through globalization and institutional variables. The idea of including entrepreneurship in the endogenous growth model is nevertheless a recent development. The pioneering endogenous growth or "new growth" models by Romer (1986, 1990) and Lucas (1988) despite acknowledging knowledge as endogenous do not explicitly include entrepreneur in their models. However, since technologies or knowledge may be of diverse types and have different sources, such as basic scientific research, private R\&D and innovation, or learning by doing, Aghion and Howitt (1992) argue that on the basis of the Schumpeterian concept of "creative destruction", entrepreneur holds a central position in the endogenous growth models since all $\mathrm{R} \& \mathrm{D}$ and investment decisions are made by forward-looking profit maximizing entrepreneurs. Formally, these authors then include entrepreneurship in their endogenous growth models by connecting purposive, profit-seeking investment in knowledge to the persons performing this task: entrepreneurs (Karlsson et al. (2004). To them, entrepreneurs destroy the previous product in order to create a new product.

On the basis of the above theoretical foundation, we specify a model that relates entrepreneurship to economic growth, while controlling for country specific factors, which may impact growth. An augmented production function that includes an explicit measure of entrepreneurship to be estimated would therefore appear in a Cobb-Douglas form as follows:

$$
Y_{i t}=A K_{i t}^{\beta_{1}} L_{i t}^{\beta_{2}}
$$

Where $i$ stands for the $i$ th cross-sectional unit and $\mathrm{t}$ for the $t$ th time period; $\mathrm{K}$ is capital; $\mathrm{L}$ is labor; A is technology. To get per capita values we divide through by population and taking natural logs:

$$
\ln \left(\frac{Y_{i t}}{N_{i t}}\right)=\ln \left(A_{i t}\right)+\beta_{1} \ln \left(\frac{K_{i t}}{N_{i t}}\right)+\beta_{2} \ln \left(\frac{L_{i t}}{N_{i t}}\right)
$$

In line with Doran et al. (2018), Audretsch and Keilbach (2008), Stam and van Stel (2009), we consider entrepreneurship as endogenous in the model by letting $\ln \left(A_{i t}\right)=\beta_{0}+\phi \ln E N T_{i t}+\varepsilon_{i t}$. So, we rewrite equation (2) to get:

$$
\ln \left(\frac{Y_{i t}}{N_{i t}}\right)=\beta_{0}+\phi \ln E N T_{i t}+\beta_{2} \ln \left(\frac{K_{i t}}{N_{i t}}\right)+\beta_{3} \ln \left(\frac{L_{i t}}{N_{i t}}\right)+\varepsilon_{i t}
$$

Here $\ln E N T_{i t}$ is natural logarithm of entrepreneurship; $\ln \left(Y_{i t} / N_{i t}\right)$ is natural logarithm of real GDP per capita (GDPPC); $\ln \left(K_{i t} / N_{i t}\right)$ natural logarithm of capital stock per capita, proxied by Gross Fixed Capital Formation 
$(\mathrm{GFCF}) ; \ln \left(L_{i t} / N_{i t}\right)$ the natural logarithm of employment per capita (i.e. the employment rate), proxied by labor force as percentage of total population (LBR); $\beta_{i}$ are the coefficients; $i$ is country, running from 1 to $\mathrm{N} ; t$ is time period, running from 1 to $\mathrm{T}$; $\varepsilon_{i t}$ is error term. Consequently our model that includes explanatory and control variables turns out to be:

$$
\ln G D P P C_{i t}=\beta_{0}+\phi \ln E N T_{i t}+\alpha_{i} \sum_{i=1}^{n} X_{i t}+\varepsilon_{i t}
$$

where $X_{i t}$ are the other explanatory variables including those defined above and other control variables identified but commonly used in growth literature. The latter include exports (lnEXPORT), trade in services (InTRADE_SER), macroeconomic stability proxied by inflation (INFL_GDP), government consumption (lnGOVCONS), personal remittances (lnREM), and, internet (lnINTERNET).

Since our focus is sector-wide GDP, we rewrite equation (3) in summary as follows:

$$
\ln S E C T O R_{i t}=\beta_{0}+\beta_{1} \ln E N T_{i t}+\alpha_{i} \sum_{i=1}^{n} X_{i t}+\varepsilon_{i t}
$$

The dependent variable $S E C T O R_{i t}$ is threefold: the agriculture, manufacturing and services sectors, estimated individually as per our earlier argument.

Furthermore, as alluded to earlier on, the observed effect on growth if any, would be driven by inter alia institutional quality, globalization, financial sophistication, financial depth, human capital and the level of economic development. We therefore introduce interactions to examine the extent to which these channels would influence the entrepreneurship-growth nexus. We focus on the first four here represented by $Z_{i t}$. These are in particular, political stability (POLSTAB) to capture institutional quality; credit to private sector (CREDIT) to capture financial depth; money supply (M2) to capture financial sophistication; and, globalization (GLOB) to capture openness. The latter is represented by economic globalization and political globalization.

$$
\ln S_{E C T O R}=\beta_{0}+\beta_{1}\left(\ln E N T_{i t} * \ln Z_{i t}\right)+\alpha_{i} \sum_{i=1}^{n} \ln X_{i t}+\varepsilon_{i t}
$$

We include the entrepreneurship $\ln E N T_{i t}$ and its square to test the inverted $U$ relationship between entrepreneurship and sectoral growth predicted by the model. That is, it is also possible that the relationship between entrepreneurship and sectoral growth may be non-linear. In line with Wennekers et al., (2005), we thus test for nonlinearity of our model as exhibited in the following equations (7) and (8):

$$
\ln G D P P C_{i t}=\beta_{0}+\phi_{1} \ln E N T_{i t}+\phi_{2} \ln E N T_{i t}^{2}+\alpha_{i} \sum_{i=1}^{n} X_{i t}+\varepsilon_{i t}
$$

And, for testing non-linearity as explained earlier,

$$
\ln S E C T O R_{i t}=\beta_{0}+\phi_{1} \ln E N T_{i t}+\phi_{2} \ln E N T_{i t}^{2}+\alpha_{i} \sum_{i=1}^{n} X_{i t}+\varepsilon_{i t}
$$

\subsection{Estimation Techniques}

The study estimates our model using the pooled OLS, since the $\mathrm{N}$ and $\mathrm{T}$ are both small $(\mathrm{N}=13, \mathrm{~T}=11)$. However, the pooled regression may result in heterogeneity bias if there is reason to worry about the presence of individual heterogeneity, and therefore lead to biased and inconsistent estimates especially if the time dimension of the panel is fixed and small (see Nickell, 1981; Judson \& Owen, 1999). Consequently, the coefficients of the explanatory variables would likely be subject to a downward bias towards zero in absolute terms. However, given the nature of our sample, we believe there is no serious heterogeneity and therefore it is recommended to use the technique in our context as it has fewer disadvantages than applying other panel techniques such as Random Effects, Fixed Effects or GMM technique suggested by Anderson and Hsiao (1981). Agreeable among economists is that Pooled OLS can be used to derive unbiased and consistent estimates of parameters even when time constant attributes are present (Maddala, 2001), although random effects would be more efficient. In our case, both random effects and fixed effects estimators are not applicable given the small sample and short time period under consideration. According to Green (2011), it is recommended to solve endogeneity problems that would accrue from models such as ours by adopting generalized method of moments (GMM) estimators, and the system GMM in particular proposed by Arellano and Bover (1995) and Blundell and Bond (1998). The latter is based on asymptotic and small sample properties, to diminish any potential biases in finite samples. It is important to note however, that given the size of our sample and the short time period, the system GMM is not 
applicable given the requirement of many instruments. Therefore, using the assumption that all coefficients are constant across time and individuals, we assume that there is neither significant country nor significant temporal effects and pool all of the data and run an ordinary least squares (OLS) regression model.

\subsection{Data}

Several measures of entrepreneurship exist. Among these are the entry density, the entry rate and business density, all of which are sourced from the World Bank Group Entrepreneurs Survey (WBGES). While the entry density measure captures the number of newly registered limited-liability firms per 1000 working age population, the entry rate is calculated as the ratio of new firms to the total number of lagged registered businesses. Alternative measures sourced from Global Entrepreneurship Monitor (GEM) research of 1999 include inter alia the Total entrepreneurial activity (TEA) index that measures the percentage of those who are in the nascent phase of the business or owners and managers of a young firm in the 18-64 age population, Necessity-based entrepreneurs, new business start-ups, and the Opportunity-based entrepreneurs. However, the general use of TEA has been widely criticized mainly because it captures just only one, aspect of entrepreneurship (Szerb, 2008). The Global entrepreneurship index (GEI) is the most recent one in addition to the previous Complex Entrepreneurship Context index developed by Acs and Szerb (2008). Given the high degree of correlation observed among these measures (Reynolds et al., 2005), and on basis of data availability, we consider it sufficient to adopt one measure in the current study, the business density measure, that captures number of existing registered companies with limited liability per 1,000 working age population, given that Entrepreneurship is generally defined as the creation of new firms. According to the World Bank's Doing Business database, the proxy for this measure the new business registration per one thousand people aged 15-64. The source of data on entrepreneurship, as well as other variables used in the study is presented in Table 2 . The description of the data is reported in Table 3 while Table 4 displays the pairwise correlation of the explanatory variables. It is notable here that the highly correlated variables such as credit and M2 are not included in same model during estimation.

Table 3a. Definition and source of variables

\begin{tabular}{|c|c|c|}
\hline Variable & Description & Source \\
\hline $\operatorname{lnGDPPC}$ & $\begin{array}{l}\text { GDP per capita (constant } 2010 \text { US\$). It is gross domestic product divided by } \\
\text { midyear population. }\end{array}$ & World Bank (WDI) \\
\hline $\ln A G R I C$ & $\begin{array}{l}\text { Agriculture, value added (\% of GDP). Agriculture includes forestry, hunting, } \\
\text { and fishing, as well as cultivation of crops and livestock production. }\end{array}$ & World Bank (WDI) \\
\hline $\operatorname{lnMAN}$ & Manufacturing, value added (\% of GDP). & World Bank (WDI) \\
\hline $\operatorname{lnSERV}$ & Services, value added ( $\%$ of GDP). & World Bank (WDI) \\
\hline $\operatorname{lnENT}$ & Business density: new registrations per 1,000 people ages $15-64)$ & $\begin{array}{l}\text { World Bank Group Entrepreneurship } \\
\text { Survey (WBGES) and database }\end{array}$ \\
\hline $\operatorname{lnLBR}$ & $\begin{array}{l}\text { Labor force, total. It comprises people ages } 15 \text { and older who supply labor for } \\
\text { the production of goods and services during a specified period. }\end{array}$ & World Bank (WDI) \\
\hline $\operatorname{lnGFCF}$ & Gross fixed capital formation (\% of GDP). & World Bank (WDI) \\
\hline $\operatorname{lnEXPORT}$ & Exports of Commodities ( $\%$ of GDP). & World Bank (WDI) \\
\hline InTRADE_SER & Trade in services ( $\%$ of GDP). & World Bank (WDI) \\
\hline Inflation & Inflation, GDP deflator (annual \%). & World Bank (WDI) \\
\hline $\operatorname{lnGOV}$ & Government consumption expenditure ( $\%$ of GDP). & World Bank (WDI) \\
\hline $\operatorname{lnREM}$ & Personal remittances, received ( $\%$ of GDP). & World Bank (WDI) \\
\hline InINTERNET & Internet penetration (per 100 people) & World Bank (WDI) \\
\hline $\ln \mathrm{M} 2$ & $\begin{array}{l}\text { Broad money and quasi money ( } \% \text { of GDP) or money supply variable. It is a } \\
\text { proxy for financial sophistication. }\end{array}$ & World Bank (WDI) \\
\hline $\operatorname{lnCREDIT}$ & Domestic credit to private sector (\% of GDP). It is a proxy for financial depth. & World Bank (WDI) \\
\hline $\operatorname{lnKOFECGI~}$ & Economic globalization index. KOF* sub-index. & Gygli et al. (2018) \& Dreher (2006). \\
\hline $\operatorname{lnKOFPOGI}$ & Political globalization index. KOF sub-index. & Gygli et al. (2018) \& Dreher (2006). \\
\hline $\operatorname{lnPOL} \_$stab & $\begin{array}{l}\text { Political stability and absence of violence index. Estimate gives the country's } \\
\text { score on the aggregate indicator, in units of a standard normal distribution, i.e. } \\
\text { ranging from approximately }-2.5 \text { to } 2.5 \text {. }\end{array}$ & $\begin{array}{l}\text { WGI by Kauffmann and Kraay } \\
\text { (2018). }\end{array}$ \\
\hline
\end{tabular}

*KOF is an acronym for the German word "Konjunkturforschungsstelle" meaning: Economic cycle research institute. The KOF Index of Globalization is an index of the degree of globalization of countries. It was conceived by Axel Dreher at the Konjunkturforschungsstelle of ETH Zurich, Switzerland. 
Table 3b. Description statistics of variables

\begin{tabular}{|c|c|c|c|c|c|}
\hline Variable & Obs & Mean & Std.Dev. & Min & Max \\
\hline $\operatorname{lnGDPPC}$ & 132 & 7.465 & 1.147 & 5.726 & 9.192 \\
\hline $\ln A G R I C$ & 132 & 2.423 & 1.041 & .717 & 4.072 \\
\hline $\operatorname{lnMAN}$ & 132 & 2.236 & .596 & .427 & 3.083 \\
\hline lnSERV & 132 & 3.901 & .232 & 3.349 & 4.54 \\
\hline $\operatorname{lnENT}$ & 132 & -.244 & 1.879 & -4.782 & 2.911 \\
\hline $\operatorname{lnLBR}$ & 132 & 15.204 & 1.446 & 13.209 & 17.865 \\
\hline $\operatorname{lnGFCF}$ & 132 & 3.077 & .333 & 2.112 & 3.727 \\
\hline $\operatorname{lnEXPORT}$ & 132 & 3.465 & .435 & 2.221 & 4.119 \\
\hline InTRADE_SER & 130 & 2.742 & .527 & 1.342 & 3.915 \\
\hline Inflation & 132 & 6.922 & 10.22 & -4.321 & 103.823 \\
\hline $\operatorname{lnGOV}$ & 132 & 2.731 & .421 & 1.683 & 3.649 \\
\hline $\operatorname{lnREM}$ & 132 & .152 & 2.318 & -5.402 & 3.557 \\
\hline InINTERNET & 131 & 2.171 & 1.333 & -1.48 & 4.065 \\
\hline $\operatorname{lnM} 2$ & 132 & 3.634 & .711 & 1.782 & 4.774 \\
\hline lnCREDIT & 132 & 3.239 & 1.036 & .734 & 5.076 \\
\hline lnKOFECGI & 132 & 3.901 & .239 & 3.247 & 4.411 \\
\hline lnKOFPOGI & 132 & 4.173 & .23 & 3.59 & 4.489 \\
\hline lnPOL_stab & 132 & 3.428 & 1.042 & -.034 & 4.541 \\
\hline
\end{tabular}

Table 4. Pairwise correlation

\begin{tabular}{|c|c|c|c|c|c|c|c|c|c|c|c|c|c|c|}
\hline Variables & (1) & (2) & (3) & (4) & (5) & (6) & (7) & (8) & (9) & $(10)$ & (11) & $(12)$ & (13) & (14) \\
\hline (1) $\operatorname{lnENT}$ & 1.00 & & & & & & & & & & & & & \\
\hline (2) $\ln L B R$ & -0.32 & 1.00 & & & & & & & & & & & & \\
\hline (3) $\operatorname{lnGFCF}$ & 0.40 & -0.39 & 1.00 & & & & & & & & & & & \\
\hline (4) $\operatorname{lnEXPORT}$ & 0.29 & -0.44 & 0.29 & 1.00 & & & & & & & & & & \\
\hline (5) $\operatorname{lnTrade\_ Serv}$ & 0.20 & -0.55 & 0.34 & 0.40 & 1.00 & & & & & & & & & \\
\hline (6) INFL_GDP & -0.14 & 0.17 & -0.19 & -0.10 & -0.26 & 1.00 & & & & & & & & \\
\hline (7) $\operatorname{lnGOV}$ & 0.45 & -0.48 & 0.60 & 0.41 & 0.22 & -0.21 & 1.00 & & & & & & & \\
\hline (8) $\operatorname{lnREM}$ & -0.28 & 0.19 & 0.02 & -0.26 & -0.12 & -0.05 & 0.13 & 1.00 & & & & & & \\
\hline (9) lnInternet & 0.70 & -0.03 & 0.43 & 0.23 & 0.24 & -0.25 & 0.36 & -0.07 & 1.00 & & & & & \\
\hline (10) $\operatorname{lnM} 2$ & 0.69 & -0.30 & 0.43 & 0.49 & 0.48 & -0.31 & 0.45 & -0.12 & 0.71 & 1.00 & & & & \\
\hline (11) $\operatorname{lnCREDIT}$ & 0.72 & -0.13 & 0.35 & 0.35 & 0.29 & -0.25 & 0.41 & -0.23 & 0.75 & 0.90 & 1.00 & & & \\
\hline (12) $\operatorname{lnKOFECGI}$ & 0.70 & -0.61 & 0.36 & 0.58 & 0.69 & -0.23 & 0.40 & -0.18 & 0.53 & 0.72 & 0.62 & 1.00 & & \\
\hline (13) $\operatorname{lnKOFPOGI}$ & -0.10 & 0.78 & -0.18 & -0.28 & -0.26 & 0.00 & -0.32 & 0.19 & 0.28 & 0.17 & 0.31 & -0.28 & 1.00 & \\
\hline (14) lnPOL_stab & 0.60 & -0.79 & 0.52 & 0.28 & 0.48 & -0.31 & 0.57 & -0.10 & 0.35 & 0.62 & 0.53 & 0.67 & -0.42 & 1.00 \\
\hline
\end{tabular}

\section{Results}

Table 5 shows the linear regression results with robust standard errors. Consistent with the previous findings (e.g. Raoofi et al., 2014; van Stel et al., 2004, 2005; Audretsch et al., 2006; and, Koo \& Kim, 2009), entrepreneurship is significantly important for economic growth as evident in Columns 1 and 2 where the relevant proxy is included individually and together with other control variables respectively. The relevant coefficient in both specifications is observed positive and highly significant at 1 percent statistical level.

Table 5. Entrepreneurship and economic growth - linear

\begin{tabular}{|c|c|c|c|c|c|c|c|c|}
\hline & $\begin{array}{c}(1) \\
\text { GDPPC }\end{array}$ & $\begin{array}{c}(2) \\
\text { GDPPC }\end{array}$ & $\begin{array}{c}(3) \\
\text { AGRIC }\end{array}$ & $\begin{array}{c}(4) \\
\text { AGRIC } \\
\end{array}$ & $\begin{array}{c}(5) \\
\text { MAN }\end{array}$ & $\begin{array}{c}(6) \\
\text { MAN }\end{array}$ & $\begin{array}{c}(7) \\
\text { SERV }\end{array}$ & $\begin{array}{c}(8) \\
\text { SERV }\end{array}$ \\
\hline $\operatorname{lnENT}$ & $\begin{array}{c}0.521 * * * \\
(0.022)\end{array}$ & $\begin{array}{c}0.328 * * * \\
(0.041)\end{array}$ & $\begin{array}{c}-0.425 * * * \\
(0.035)\end{array}$ & $\begin{array}{c}-0.264 * * * \\
(0.033)\end{array}$ & $\begin{array}{c}0.024 \\
(0.026)\end{array}$ & $\begin{array}{c}-0.123 * * * \\
(0.026)\end{array}$ & $\begin{array}{c}0.068 * * * \\
(0.008)\end{array}$ & $\begin{array}{c}0.044 * * * \\
(0.013)\end{array}$ \\
\hline $\operatorname{lnLBR}$ & & $\begin{array}{l}-0.028 \\
(0.041)\end{array}$ & & $\begin{array}{c}-0.076^{* *} \\
(0.038)\end{array}$ & & $\begin{array}{c}0.268 * * * \\
(0.036)\end{array}$ & & $\begin{array}{c}0.026 \\
(0.016)\end{array}$ \\
\hline $\operatorname{lnGFCF}$ & & $\begin{array}{c}-0.202 * \\
(0.121)\end{array}$ & & $\begin{array}{l}-0.109 \\
(0.154)\end{array}$ & & $\begin{array}{l}-0.209 \\
(0.130)\end{array}$ & & $\begin{array}{c}-0.325 * * * \\
(0.063)\end{array}$ \\
\hline
\end{tabular}




\begin{tabular}{|c|c|c|c|c|c|c|c|c|}
\hline $\operatorname{lnEXPORT}$ & & $\begin{array}{c}0.756 * * * \\
(0.100)\end{array}$ & & $\begin{array}{c}-0.660 * * * \\
(0.110)\end{array}$ & & $\begin{array}{c}0.412 * * * \\
(0.098)\end{array}$ & & $\begin{array}{l}-0.010 \\
(0.045)\end{array}$ \\
\hline InTRADE_SER & & $\begin{array}{c}-0.498^{*} * * \\
(0.106)\end{array}$ & & $\begin{array}{c}0.371 * * * \\
(0.083)\end{array}$ & & $\begin{array}{c}0.253 * * \\
(0.101)\end{array}$ & & $\begin{array}{c}0.072 * * \\
(0.031)\end{array}$ \\
\hline INFL_GDP & & $\begin{array}{c}0.002 \\
(0.002)\end{array}$ & & $\begin{array}{c}0.002 \\
(0.002)\end{array}$ & & $\begin{array}{l}-0.002 \\
(0.002)\end{array}$ & & $\begin{array}{c}0.001 \\
(0.001)\end{array}$ \\
\hline lnGOVCONS & & $\begin{array}{c}0.043 \\
(0.132)\end{array}$ & & $\begin{array}{c}-0.979 * * * \\
(0.136)\end{array}$ & & $\begin{array}{c}0.964 * * * \\
(0.163)\end{array}$ & & $\begin{array}{c}0.188^{* * * *} \\
(0.055)\end{array}$ \\
\hline $\operatorname{lnREM}$ & & $\begin{array}{c}-0.097 * * * \\
(0.019)\end{array}$ & & $\begin{array}{c}0.143 * * * \\
(0.019)\end{array}$ & & $\begin{array}{c}-0.078^{* * *} \\
(0.017)\end{array}$ & & $\begin{array}{c}0.001 \\
(0.008)\end{array}$ \\
\hline InINTERNET & & $\begin{array}{c}0.282 * * * \\
(0.047)\end{array}$ & & $\begin{array}{c}0.005 \\
(0.046)\end{array}$ & & $\begin{array}{l}0.119 * * \\
(0.047)\end{array}$ & & $\begin{array}{c}0.064 * * * \\
(0.017)\end{array}$ \\
\hline Constant & $\begin{array}{c}7.592 * * * \\
(0.052)\end{array}$ & $\begin{array}{c}6.609 * * * \\
(0.922)\end{array}$ & $\begin{array}{c}2.319 * * * \\
(0.056)\end{array}$ & $\begin{array}{c}7.753 * * * \\
(0.953)\end{array}$ & $\begin{array}{c}2.242^{* * *} \\
(0.050)\end{array}$ & $\begin{array}{c}-6.207 * * * \\
(1.175)\end{array}$ & $\begin{array}{c}3.917 * * * \\
(0.016)\end{array}$ & $\begin{array}{c}3.695 * * * \\
(0.414)\end{array}$ \\
\hline Observations & 132 & 129 & 132 & 129 & 132 & 129 & 132 & 129 \\
\hline R-squared & 0.727 & 0.882 & 0.587 & 0.853 & 0.006 & 0.569 & 0.308 & 0.514 \\
\hline
\end{tabular}

Robust standard errors in parentheses; *** $\mathrm{p}<0.01$, ** $\mathrm{p}<0.05$, * $\mathrm{p}<0.1$.

Regarding the main focus of the current paper, the results from the three sectors are presented in Table 5 . Interestingly, while we observe a positive relationship between entrepreneurship and aggregate GDP per capita, the corresponding entrepreneurial effects on the sectors is not uniform. For example, whereas in the agriculture and manufacturing sectors we observe a negatively significant effect, it is only in the service sector that appears to relate positively with entrepreneurship. In specific terms, a 1 percent change in entrepreneurship translates into 0.044 percent change in the service sector share in GDP. Our finding of the negative association between entrepreneurship and agriculture is in nevertheless in opposition to that reported in a country-based analysis by Chenaa and Kimengsi (2016). The difference could perhaps be attributed to the nature of data, where a panel analysis might differ from individual country time series analysis. Also, it is important to note that allowing for non-linear relationship (see Table 6) between entrepreneurship does not appear to substantially alter the results from the linear model.

Turning to the hypotheses that the role of entrepreneurship on growth is conditional on financial development, institutional quality and globalization, the results are reported in Tables 7-10. While it is evident that overall the presence of financial depth (here proxied by credit to private sector), matters for the entrepreneurship-growth nexus, as the total marginal effect is $0.29(0.424+-0.042[3.239])$, the relationship appears to matter only for the services sector. In the case of the agriculture sector and manufacturing sector, the negative interaction coefficients imply that the effect of the combined action of the two predictors is less than the sum of the individual effects. Essentially, the association between one of entrepreneurship and either sector decreases if credit depth increases. When it comes to the other indicator of financial development, the financial sophistication, Table 8 shows that while the relationship between entrepreneurship and agriculture depends on financial sophistication (see Column 2), it is clear from Column (6) that the conditionality is equally a sine qua non in the manufacturing and services model but not in the agriculture specification in Column (4).

Table 6. Entrepreneurship and growth in Africa - non-linearity

\begin{tabular}{|c|c|c|c|c|c|c|c|c|}
\hline & $\begin{array}{c}(1) \\
\text { GDPPC }\end{array}$ & $\begin{array}{c}(2) \\
\text { GDPPC }\end{array}$ & $\begin{array}{c}(3) \\
\text { AGRIC }\end{array}$ & $\begin{array}{c}(4) \\
\text { AGRIC }\end{array}$ & $\begin{array}{c}(5) \\
\text { MAN }\end{array}$ & $\begin{array}{c}(6) \\
\text { MAN }\end{array}$ & $\begin{array}{c}(7) \\
\text { SERV }\end{array}$ & $\begin{array}{c}(8) \\
\text { SERV }\end{array}$ \\
\hline $\operatorname{lnENT}$ & $\begin{array}{c}0.572 * * * \\
(0.019)\end{array}$ & $\begin{array}{c}0.313^{* * * *} \\
(0.046)\end{array}$ & $\begin{array}{c}-0.539 * * * \\
(0.022)\end{array}$ & $\begin{array}{c}-0.360^{* * * *} \\
(0.026)\end{array}$ & $\begin{array}{l}0.058^{*} \\
(0.032)\end{array}$ & $\begin{array}{c}-0.122 * * * \\
(0.030)\end{array}$ & $\begin{array}{c}0.063 * * * \\
(0.010)\end{array}$ & $\begin{array}{c}0.044 * * * \\
(0.014)\end{array}$ \\
\hline ENT_SQ & $\begin{array}{c}0.039 * * * \\
(0.009)\end{array}$ & $\begin{array}{l}-0.012 \\
(0.020)\end{array}$ & $\begin{array}{c}-0.088 * * * \\
(0.009)\end{array}$ & $\begin{array}{c}-0.075^{* * * *} \\
(0.010)\end{array}$ & $\begin{array}{c}0.026^{* *} \\
(0.010)\end{array}$ & $\begin{array}{c}0.001 \\
(0.009)\end{array}$ & $\begin{array}{l}-0.004 \\
(0.004)\end{array}$ & $\begin{array}{l}-0.000 \\
(0.005)\end{array}$ \\
\hline $\operatorname{lnLBR}$ & & $\begin{array}{l}-0.014 \\
(0.051)\end{array}$ & & $\begin{array}{c}0.010 \\
(0.032)\end{array}$ & & $\begin{array}{c}0.266^{* * * *} \\
(0.036)\end{array}$ & & $\begin{array}{c}0.026 \\
(0.017)\end{array}$ \\
\hline $\operatorname{lnGFCF}$ & & $\begin{array}{l}-0.184 \\
(0.131)\end{array}$ & & $\begin{array}{c}0.005 \\
(0.117)\end{array}$ & & $\begin{array}{l}-0.211 \\
(0.130)\end{array}$ & & $\begin{array}{c}-0.324 * * * * \\
(0.063)\end{array}$ \\
\hline lnEXPORT & & $\begin{array}{c}0.798 * * * \\
(0.116)\end{array}$ & & $\begin{array}{c}-0.396^{* * * *} \\
(0.107)\end{array}$ & & $\begin{array}{c}0.408 * * * \\
(0.106)\end{array}$ & & $\begin{array}{l}-0.009 \\
(0.052)\end{array}$ \\
\hline
\end{tabular}




\begin{tabular}{|c|c|c|c|c|c|c|c|c|}
\hline InTRADE_SER & & $\begin{array}{c}-0.495 * * * \\
(0.102)\end{array}$ & & $\begin{array}{c}0.387 * * * \\
(0.077)\end{array}$ & & $\begin{array}{c}0.253 * * \\
(0.102)\end{array}$ & & $\begin{array}{c}0.072 * * \\
(0.031)\end{array}$ \\
\hline Inflation & & $\begin{array}{c}0.001 \\
(0.002)\end{array}$ & & $\begin{array}{c}0.000 \\
(0.002)\end{array}$ & & $\begin{array}{l}-0.002 \\
(0.002)\end{array}$ & & $\begin{array}{c}0.001 \\
(0.001)\end{array}$ \\
\hline lnGOVCONS & & $\begin{array}{c}0.047 \\
(0.133)\end{array}$ & & $\begin{array}{c}-0.958^{* * *} \\
(0.117)\end{array}$ & & $\begin{array}{c}0.964 * * * \\
(0.163)\end{array}$ & & $\begin{array}{c}0.188 * * * \\
(0.055)\end{array}$ \\
\hline lnREM & & $\begin{array}{c}-0.112 * * * \\
(0.035)\end{array}$ & & $\begin{array}{c}0.052 * * * \\
(0.017)\end{array}$ & & $\begin{array}{c}-0.077 * * * \\
(0.018)\end{array}$ & & $\begin{array}{c}0.001 \\
(0.009)\end{array}$ \\
\hline InINTERNET & & $\begin{array}{c}0.269 * * * \\
(0.055)\end{array}$ & & $\begin{array}{c}-0.076^{*} \\
(0.039)\end{array}$ & & $\begin{array}{c}0.120 * * \\
(0.049)\end{array}$ & & $\begin{array}{c}0.064^{* * * *} \\
(0.018)\end{array}$ \\
\hline Constant & $\begin{array}{c}7.464 * * * \\
(0.075)\end{array}$ & $\begin{array}{c}6.252 * * * \\
(1.213)\end{array}$ & $\begin{array}{c}2.606 * * * \\
(0.067)\end{array}$ & $\begin{array}{c}5.511 * * * \\
(0.851)\end{array}$ & $\begin{array}{c}2.156^{* * * *} \\
(0.067)\end{array}$ & $\begin{array}{c}-6.171 * * * \\
(1.183)\end{array}$ & $\begin{array}{c}3.931 * * * \\
(0.023)\end{array}$ & $\begin{array}{c}3.689 * * * \\
(0.431)\end{array}$ \\
\hline Observations & 132 & 129 & 132 & 129 & 132 & 129 & 132 & 129 \\
\hline R-squared & 0.750 & 0.883 & 0.729 & 0.898 & 0.044 & 0.569 & 0.314 & 0.514 \\
\hline
\end{tabular}

Robust standard errors in parentheses; *** $\mathrm{p}<0.01, * * \mathrm{p}<0.05, * \mathrm{p}<0.1$.

Table 7. Entrepreneurship in Africa - financial depth

\begin{tabular}{|c|c|c|c|c|c|c|c|c|}
\hline & $\begin{array}{c}(1) \\
\text { GDPPC }\end{array}$ & $\begin{array}{c}(2) \\
\text { GDPPC }\end{array}$ & $\begin{array}{c}(3) \\
\text { AGRIC }\end{array}$ & $\begin{array}{c}(4) \\
\text { AGRIC }\end{array}$ & $\begin{array}{c}(5) \\
\text { MAN }\end{array}$ & $\begin{array}{c}\text { (6) } \\
\text { MAN }\end{array}$ & $\begin{array}{c}\text { (7) } \\
\text { SERV }\end{array}$ & $\begin{array}{c}(8) \\
\text { SERV }\end{array}$ \\
\hline $\operatorname{lnENT}$ & $\begin{array}{c}0.302 * * * \\
(0.028)\end{array}$ & $\begin{array}{c}0.424 * * * \\
(0.104)\end{array}$ & $\begin{array}{c}-0.260^{* * * *} \\
(0.036)\end{array}$ & $\begin{array}{c}0.246 * * * \\
(0.084)\end{array}$ & $\begin{array}{c}-0.114 * * * \\
(0.030)\end{array}$ & $\begin{array}{l}-0.008 \\
(0.086)\end{array}$ & $\begin{array}{c}0.041 \text { **** } \\
(0.012)\end{array}$ & $\begin{array}{l}0.092 * \\
(0.049)\end{array}$ \\
\hline $\operatorname{lnLBR}$ & $\begin{array}{l}-0.049 \\
(0.031)\end{array}$ & $\begin{array}{l}-0.009 \\
(0.042)\end{array}$ & $\begin{array}{c}-0.072 * \\
(0.040)\end{array}$ & $\begin{array}{l}0.094 * \\
(0.052)\end{array}$ & $\begin{array}{c}0.273 * * * \\
(0.025)\end{array}$ & $\begin{array}{c}0.308 * * * \\
(0.035)\end{array}$ & $\begin{array}{c}0.022 \\
(0.015)\end{array}$ & $\begin{array}{l}0.039^{*} \\
(0.021)\end{array}$ \\
\hline lnGFCF_gdp & $\begin{array}{c}0.016 \\
(0.101)\end{array}$ & $\begin{array}{l}-0.029 \\
(0.097)\end{array}$ & $\begin{array}{l}-0.112 \\
(0.152)\end{array}$ & $\begin{array}{c}-0.300 * * \\
(0.146)\end{array}$ & $\begin{array}{l}-0.105 \\
(0.135)\end{array}$ & $\begin{array}{l}-0.144 \\
(0.138)\end{array}$ & $\begin{array}{c}-0.271^{* * *} * \\
(0.064)\end{array}$ & $\begin{array}{c}-0.290 \text { *** } \\
(0.065)\end{array}$ \\
\hline lnEXPORT_gdp & $\begin{array}{c}0.674 * * * \\
(0.086)\end{array}$ & $\begin{array}{c}0.680 * * * \\
(0.087)\end{array}$ & $\begin{array}{c}-0.669 * * * \\
(0.098)\end{array}$ & $\begin{array}{c}-0.644 * * * \\
(0.089)\end{array}$ & $\begin{array}{c}0.420 * * * \\
(0.090)\end{array}$ & $\begin{array}{c}0.426^{* * * *} \\
(0.091)\end{array}$ & $\begin{array}{l}-0.020 \\
(0.043)\end{array}$ & $\begin{array}{l}-0.017 \\
(0.043)\end{array}$ \\
\hline InTRADE_SER & $\begin{array}{c}-0.569 * * * \\
(0.080)\end{array}$ & $\begin{array}{c}-0.534 * * * \\
(0.078)\end{array}$ & $\begin{array}{c}0.381 * * * \\
(0.087)\end{array}$ & $\begin{array}{c}0.526 * * * \\
(0.088)\end{array}$ & $\begin{array}{c}0.242^{* *} \\
(0.108)\end{array}$ & $\begin{array}{c}0.272^{* *} \\
(0.107)\end{array}$ & $\begin{array}{l}0.057 * \\
(0.032)\end{array}$ & $\begin{array}{c}0.071^{* *} \\
(0.033)\end{array}$ \\
\hline INFL_GDP & $\begin{array}{l}0.003 * \\
(0.002)\end{array}$ & $\begin{array}{l}0.003^{*} \\
(0.002)\end{array}$ & $\begin{array}{c}0.002 \\
(0.002)\end{array}$ & $\begin{array}{c}0.002 \\
(0.002)\end{array}$ & $\begin{array}{l}-0.002 \\
(0.003)\end{array}$ & $\begin{array}{l}-0.002 \\
(0.002)\end{array}$ & $\begin{array}{c}0.001 \\
(0.001)\end{array}$ & $\begin{array}{c}0.001 \\
(0.001)\end{array}$ \\
\hline lnGOVCONS & $\begin{array}{l}-0.157 \\
(0.131)\end{array}$ & $\begin{array}{l}-0.066 \\
(0.139)\end{array}$ & $\begin{array}{c}-0.962 * * * \\
(0.143)\end{array}$ & $\begin{array}{c}-0.586^{* * *} \\
(0.158)\end{array}$ & $\begin{array}{c}0.879 * * * \\
(0.172)\end{array}$ & $\begin{array}{c}0.957 * * * \\
(0.179)\end{array}$ & $\begin{array}{c}0.138^{* *} \\
(0.054)\end{array}$ & $\begin{array}{c}0.176^{* * * *} \\
(0.061)\end{array}$ \\
\hline $\operatorname{lnREM}$ & $\begin{array}{c}-0.064 * * * \\
(0.018)\end{array}$ & $\begin{array}{c}-0.100 * * * \\
(0.032)\end{array}$ & $\begin{array}{c}0.141 * * * \\
(0.019)\end{array}$ & $\begin{array}{l}-0.007 \\
(0.029)\end{array}$ & $\begin{array}{c}-0.064 * * * \\
(0.017)\end{array}$ & $\begin{array}{c}-0.095 * * * \\
(0.028)\end{array}$ & $\begin{array}{c}0.009 \\
(0.008)\end{array}$ & $\begin{array}{l}-0.006 \\
(0.013)\end{array}$ \\
\hline InCREDIT & $\begin{array}{c}0.473 * * * \\
(0.050)\end{array}$ & $\begin{array}{c}0.440 \text { *** } \\
(0.054)\end{array}$ & $\begin{array}{l}-0.007 \\
(0.067)\end{array}$ & $\begin{array}{c}-0.143 * * \\
(0.059)\end{array}$ & $\begin{array}{c}0.148 * * \\
(0.066)\end{array}$ & $\begin{array}{l}0.120 * \\
(0.066)\end{array}$ & $\begin{array}{c}0.103 * * * \\
(0.024)\end{array}$ & $\begin{array}{c}0.089 * * * \\
(0.024)\end{array}$ \\
\hline CRED_ENT & & $\begin{array}{l}-0.042 \\
(0.034)\end{array}$ & & $\begin{array}{c}-0.175^{* * *} \\
(0.027)\end{array}$ & & $\begin{array}{l}-0.037 \\
(0.028)\end{array}$ & & $\begin{array}{l}-0.018 \\
(0.016)\end{array}$ \\
\hline Constant & $\begin{array}{c}6.347 * * * \\
(0.805)\end{array}$ & $\begin{array}{c}5.678 * * * \\
(0.924)\end{array}$ & $\begin{array}{c}7.698 * * * \\
(0.864)\end{array}$ & $\begin{array}{c}4.921 * * * \\
(1.222)\end{array}$ & $\begin{array}{c}-6.607 * * * \\
(0.893)\end{array}$ & $\begin{array}{c}-7.186^{* * * *} \\
(0.968)\end{array}$ & $\begin{array}{c}3.598^{* * * *} \\
(0.404)\end{array}$ & $\begin{array}{c}3.318^{* * *} \\
(0.477)\end{array}$ \\
\hline Observations & 130 & 130 & 130 & 130 & 130 & 130 & 130 & 130 \\
\hline R-squared & 0.911 & 0.913 & 0.854 & 0.884 & 0.569 & 0.573 & 0.543 & 0.550 \\
\hline
\end{tabular}

Robust standard errors in parentheses; *** $\mathrm{p}<0.01, * * \mathrm{p}<0.05, * \mathrm{p}<0.1$.

On the other hand, in Table 9, the total partial effect of entrepreneurship on the GDP per capita model as well as the Agriculture and service models in the presence of political stability is respectively $0.286,0.228$, and, 0.055 , that of the manufacturing model is -0.062 . The findings imply that political stability creates an enabling environment for entrepreneurs to influence the sectors in question. Hence the importance of good institutional quality. The finding is in line with Bruns et al. (2015). Similarly, we note that globalization plays a crucial role in determining the relationship between entrepreneurship and growth. First, as evident in Tables 10, the higher the economic globalization, the greater or more positive the effect of entrepreneurship on either manufacturing or service sectors. However the overall effect is calculated positive for the GDP per capita (0.3737) and service sector (0.055) specifications. Intuitively, an increase in economic globalization affects the extent to which entrepreneurship relates to sector-wide GDP. Political globalization on the other hand, as a moderating variable 
is observed important in the explanation of the linkage between entrepreneurship and economic performance (column 2) and agriculture sector (Column 4). The relevant positive value for the effect of the interaction term would imply that the higher the political globalization, the greater or more positive the effect of entrepreneurship on either aggregate GDP per capita or the agriculture sector-wide GDP. It is also clear from the results in Table 11 that political globalization conditions the nexus between entrepreneurship and the service sector growth as evident from the overall impact of 0.055 [0.839+-0.188(4.17)]. The findings are in line with the theoretical assertion that a conducive environment characterized by improving institutional quality, globalization, and financial development is key to facilitating the role of entrepreneurship to growth. Support for our findings can be found in Aparicio (2017).

Table 8. Entrepreneurship in Africa - financial sophistication

\begin{tabular}{|c|c|c|c|c|c|c|c|c|}
\hline & $\begin{array}{c}(1) \\
\text { GDPPC }\end{array}$ & $\begin{array}{c}(2) \\
\text { GDPPC }\end{array}$ & $\begin{array}{c}(3) \\
\text { AGRIC }\end{array}$ & $\begin{array}{c}(4) \\
\text { AGRIC }\end{array}$ & $\begin{array}{c}(5) \\
\text { MAN } \\
\end{array}$ & $\begin{array}{c}(6) \\
\text { MAN } \\
\end{array}$ & $\begin{array}{c}(7) \\
\text { SERV } \\
\end{array}$ & $\begin{array}{c}(8) \\
\text { SERV } \\
\end{array}$ \\
\hline $\operatorname{lnENT}$ & $\begin{array}{c}0.231 * * * \\
(0.033)\end{array}$ & $\begin{array}{c}0.045 \\
(0.187)\end{array}$ & $\begin{array}{c}-0.274 * * * \\
(0.040)\end{array}$ & $\begin{array}{c}0.872 * * * \\
(0.162)\end{array}$ & $\begin{array}{c}-0.135^{* * *} \\
(0.028)\end{array}$ & $\begin{array}{c}-0.630 * * * \\
(0.140)\end{array}$ & $\begin{array}{c}0.037 * * * \\
(0.014)\end{array}$ & $\begin{array}{l}-0.008 \\
(0.091)\end{array}$ \\
\hline $\operatorname{lnLBR}$ & $\begin{array}{c}-0.065^{* *} \\
(0.030)\end{array}$ & $\begin{array}{c}-0.103 * * \\
(0.049)\end{array}$ & $\begin{array}{c}-0.080^{* *} \\
(0.040)\end{array}$ & $\begin{array}{c}0.157 * * * \\
(0.048)\end{array}$ & $\begin{array}{c}0.263 * * * \\
(0.034)\end{array}$ & $\begin{array}{c}0.161 * * * \\
(0.047)\end{array}$ & $\begin{array}{c}0.023 \\
(0.016)\end{array}$ & $\begin{array}{c}0.014 \\
(0.026)\end{array}$ \\
\hline $\operatorname{lnGFCF}$ & $\begin{array}{l}-0.175 \\
(0.108)\end{array}$ & $\begin{array}{l}-0.174 \\
(0.111)\end{array}$ & $\begin{array}{l}-0.106 \\
(0.154)\end{array}$ & $\begin{array}{l}-0.111 \\
(0.122)\end{array}$ & $\begin{array}{l}-0.206 \\
(0.133)\end{array}$ & $\begin{array}{l}-0.204 \\
(0.131)\end{array}$ & $\begin{array}{c}-0.323 * * * \\
(0.065)\end{array}$ & $\begin{array}{c}-0.323 \text { *** } \\
(0.066)\end{array}$ \\
\hline $\operatorname{lnEXPORT}$ & $\begin{array}{c}0.495 * * * \\
(0.091)\end{array}$ & $\begin{array}{c}0.474 * * * \\
(0.100)\end{array}$ & $\begin{array}{c}-0.686^{* * *} \\
(0.111)\end{array}$ & $\begin{array}{c}-0.556^{* * *} \\
(0.090)\end{array}$ & $\begin{array}{c}0.380 * * * \\
(0.106)\end{array}$ & $\begin{array}{c}0.324 * * * \\
(0.107)\end{array}$ & $\begin{array}{l}-0.027 \\
(0.050)\end{array}$ & $\begin{array}{l}-0.033 \\
(0.054)\end{array}$ \\
\hline InTRADE_SER & $\begin{array}{c}-0.748 * * * \\
(0.084)\end{array}$ & $\begin{array}{c}-0.797 * * * \\
(0.092)\end{array}$ & $\begin{array}{c}0.346^{* * * *} \\
(0.098)\end{array}$ & $\begin{array}{c}0.645^{* * *} * \\
(0.085)\end{array}$ & $\begin{array}{c}0.222 * * \\
(0.110)\end{array}$ & $\begin{array}{c}0.093 \\
(0.120)\end{array}$ & $\begin{array}{c}0.055 \\
(0.036)\end{array}$ & $\begin{array}{c}0.043 \\
(0.045)\end{array}$ \\
\hline INFL_GDP & $\begin{array}{c}0.006^{* *} \\
(0.002)\end{array}$ & $\begin{array}{c}0.006 * * * \\
(0.002)\end{array}$ & $\begin{array}{c}0.002 \\
(0.002)\end{array}$ & $\begin{array}{c}0.002 \\
(0.002)\end{array}$ & $\begin{array}{l}-0.001 \\
(0.002)\end{array}$ & $\begin{array}{l}-0.001 \\
(0.002)\end{array}$ & $\begin{array}{c}0.001 \\
(0.001)\end{array}$ & $\begin{array}{c}0.001 \\
(0.001)\end{array}$ \\
\hline lnGOVCONS & $\begin{array}{l}-0.007 \\
(0.107)\end{array}$ & $\begin{array}{l}-0.073 \\
(0.119)\end{array}$ & $\begin{array}{c}-0.984^{* * *} \\
(0.138)\end{array}$ & $\begin{array}{c}-0.574 * * * \\
(0.123)\end{array}$ & $\begin{array}{c}0.958 * * * \\
(0.162)\end{array}$ & $\begin{array}{c}0.781 * * * \\
(0.175)\end{array}$ & $\begin{array}{c}0.185^{* * *} \\
(0.054)\end{array}$ & $\begin{array}{c}0.168 * * * \\
(0.061)\end{array}$ \\
\hline $\operatorname{lnREM}$ & $\begin{array}{c}-0.111 \text { *** } \\
(0.018)\end{array}$ & $\begin{array}{c}-0.081 * * \\
(0.035)\end{array}$ & $\begin{array}{c}0.141 * * * \\
(0.019)\end{array}$ & $\begin{array}{c}-0.046^{*} \\
(0.028)\end{array}$ & $\begin{array}{c}-0.080 * * * \\
(0.017)\end{array}$ & $\begin{array}{c}0.001 \\
(0.032)\end{array}$ & $\begin{array}{l}-0.000 \\
(0.008)\end{array}$ & $\begin{array}{c}0.007 \\
(0.014)\end{array}$ \\
\hline lnINTERNET & $\begin{array}{c}0.182 * * * \\
(0.041)\end{array}$ & $\begin{array}{c}0.202 * * * \\
(0.045)\end{array}$ & $\begin{array}{l}-0.005 \\
(0.044)\end{array}$ & $\begin{array}{c}-0.127 * * * \\
(0.043)\end{array}$ & $\begin{array}{c}0.107 * * \\
(0.051)\end{array}$ & $\begin{array}{c}0.160 * * * \\
(0.054)\end{array}$ & $\begin{array}{c}0.058 * * * \\
(0.019)\end{array}$ & $\begin{array}{c}0.063 * * * \\
(0.021)\end{array}$ \\
\hline $\operatorname{lnM} 2$ & $\begin{array}{c}0.654 * * * \\
(0.068)\end{array}$ & $\begin{array}{c}0.687 * * * \\
(0.069)\end{array}$ & $\begin{array}{c}0.065 \\
(0.088)\end{array}$ & $\begin{array}{l}-0.142 \\
(0.087)\end{array}$ & $\begin{array}{c}0.080 \\
(0.084)\end{array}$ & $\begin{array}{l}0.170^{*} \\
(0.086)\end{array}$ & $\begin{array}{c}0.044 \\
(0.037)\end{array}$ & $\begin{array}{c}0.052 \\
(0.039)\end{array}$ \\
\hline M2_ENT & & $\begin{array}{c}0.054 \\
(0.056)\end{array}$ & & $\begin{array}{c}-0.334^{* * *} \\
(0.046)\end{array}$ & & $\begin{array}{c}0.144 * * * \\
(0.043)\end{array}$ & & $\begin{array}{c}0.013 \\
(0.026)\end{array}$ \\
\hline Constant & $\begin{array}{c}6.610 * * * \\
(0.763)\end{array}$ & $\begin{array}{c}7.360 * * * \\
(1.135)\end{array}$ & $\begin{array}{c}7.753 * * * \\
(0.943)\end{array}$ & $\begin{array}{c}3.105 * * * \\
(1.117)\end{array}$ & $\begin{array}{c}-6.207 * * * \\
(1.176)\end{array}$ & $\begin{array}{c}-4.201 * * * \\
(1.394)\end{array}$ & $\begin{array}{c}3.695 * * * \\
(0.422)\end{array}$ & $\begin{array}{c}3.881 * * * \\
(0.596)\end{array}$ \\
\hline Observations & 129 & 129 & 129 & 129 & 129 & 129 & 129 & 129 \\
\hline R-squared & 0.927 & 0.928 & 0.853 & 0.893 & 0.571 & 0.594 & 0.519 & 0.520 \\
\hline
\end{tabular}

Robust standard errors in parentheses; *** $\mathrm{p}<0.01$, ** $\mathrm{p}<0.05$, * $\mathrm{p}<0.1$.

Table 9. Entrepreneurship in Africa - Political stability

\begin{tabular}{lcccccccc}
\hline & $(1)$ & $(2)$ & $(3)$ & $(4)$ & $(5)$ & $(6)$ & $(7)$ & $(8)$ \\
& GDPPC & GDPPC & AGRIC & AGRIC & MAN & MAN & SERV & SERV \\
\hline lnENT & $0.293^{* * *}$ & $0.523^{* * *}$ & $-0.270^{* * *}$ & $0.300^{* * *}$ & -0.059 & 0.010 & $0.057^{* * *}$ & $0.117^{* *}$ \\
& $(0.041)$ & $(0.141)$ & $(0.044)$ & $(0.095)$ & $(0.037)$ & $(0.111)$ & $(0.016)$ & $(0.048)$ \\
lnGFCF & $-0.253^{* *}$ & -0.097 & -0.115 & $0.274^{* *}$ & -0.124 & -0.077 & $-0.306^{* * *}$ & $-0.265^{* * *}$ \\
& $(0.125)$ & $(0.153)$ & $(0.154)$ & $(0.129)$ & $(0.134)$ & $(0.164)$ & $(0.058)$ & $(0.064)$ \\
lnEXPORT & $0.798^{* * *}$ & $0.842^{* * *}$ & $-0.610^{* * *}$ & $-0.501^{* * *}$ & $0.205^{* *}$ & $0.218^{* *}$ & -0.035 & -0.023 \\
& $(0.107)$ & $(0.112)$ & $(0.110)$ & $(0.108)$ & $(0.092)$ & $(0.094)$ & $(0.042)$ & $(0.044)$ \\
lnTRADE_SER & $-0.551^{* * *}$ & $-0.533^{* * *}$ & $0.406^{* * *}$ & $0.452^{* * *}$ & $0.219^{* * *}$ & $0.224^{* * *}$ & $0.083^{* * *}$ & $0.087^{* * *}$ \\
& $(0.093)$ & $(0.086)$ & $(0.077)$ & $(0.074)$ & $(0.077)$ & $(0.076)$ & $(0.029)$ & $(0.027)$ \\
INFL_GDP & 0.003 & 0.002 & 0.003 & -0.001 & $-0.006^{* *}$ & $-0.007 * *$ & -0.000 & -0.001 \\
& $(0.002)$ & $(0.003)$ & $(0.003)$ & $(0.002)$ & $(0.002)$ & $(0.003)$ & $(0.001)$ & $(0.001)$ \\
\hline
\end{tabular}




\begin{tabular}{lcccccccc}
\hline lnGOVCONS & -0.010 & 0.092 & $-0.953 * * *$ & $-0.701 * * *$ & $0.954 * * *$ & $0.985^{* * *}$ & $0.200^{* * *}$ & $0.227 * * *$ \\
& $(0.141)$ & $(0.150)$ & $(0.133)$ & $(0.131)$ & $(0.142)$ & $(0.155)$ & $(0.057)$ & $(0.062)$ \\
lnREM & $-0.099 * * *$ & $-0.150^{* * *}$ & $0.138^{* * *}$ & 0.011 & $-0.061 * * *$ & $-0.077 * * *$ & 0.003 & -0.011 \\
& $(0.018)$ & $(0.037)$ & $(0.018)$ & $(0.024)$ & $(0.015)$ & $(0.026)$ & $(0.008)$ & $(0.012)$ \\
InINTERNET & $0.300^{* * *}$ & $0.255^{* * *}$ & -0.017 & $-0.130^{* * *}$ & $0.164 * * *$ & $0.150^{* * *}$ & $0.063^{* * *}$ & $0.051^{* * *}$ \\
& $(0.038)$ & $(0.042)$ & $(0.045)$ & $(0.043)$ & $(0.039)$ & $(0.049)$ & $(0.015)$ & $(0.017)$ \\
lnPOL_stab & $0.128 * *$ & -0.028 & 0.083 & $-0.304 * * *$ & $-0.420^{* * *}$ & $-0.467 * * *$ & $-0.061 * *$ & $-0.102^{* *}$ \\
& $(0.062)$ & $(0.098)$ & $(0.071)$ & $(0.089)$ & $(0.059)$ & $(0.101)$ & $(0.028)$ & $(0.043)$ \\
POL_ENT & & -0.069 & & $-0.170^{* * *}$ & & -0.021 & & -0.018 \\
& & $(0.044)$ & & $(0.025)$ & & $(0.029)$ & & $(0.013)$ \\
Constant & $5.994 * * *$ & $5.763 * * *$ & $6.029 * * *$ & $5.454 * * *$ & -0.177 & -0.247 & $4.277 * * *$ & $4.216 * * *$ \\
& $(0.398)$ & $(0.449)$ & $(0.479)$ & $(0.416)$ & $(0.423)$ & $(0.454)$ & $(0.188)$ & $(0.197)$ \\
Observations & 129 & 129 & 129 & 129 & 129 & 129 & 129 & 129 \\
R-squared & 0.886 & 0.891 & 0.850 & 0.882 & 0.586 & 0.588 & 0.530 & 0.537 \\
\hline
\end{tabular}

Robust standard errors in parentheses; $* * * \mathrm{p}<0.01, * * \mathrm{p}<0.05, * \mathrm{p}<0.1$.

Table 10. Entrepreneurship in Africa - economic globalization

\begin{tabular}{|c|c|c|c|c|c|c|c|c|}
\hline & $\begin{array}{c}(1) \\
\text { GDPPC }\end{array}$ & $\begin{array}{c}(2) \\
\text { GDPPC } \\
\end{array}$ & $\begin{array}{c}(3) \\
\text { AGRIC }\end{array}$ & $\begin{array}{c}(4) \\
\text { AGRIC }\end{array}$ & $\begin{array}{c}(5) \\
\text { MAN }\end{array}$ & $\begin{array}{c}(6) \\
\text { MAN } \\
\end{array}$ & $\begin{array}{c}(7) \\
\text { SERV }\end{array}$ & $\begin{array}{c}(8) \\
\text { SERV }\end{array}$ \\
\hline \multirow[t]{2}{*}{$\operatorname{lnENT}$} & $0.317 * * *$ & $2.132 * * *$ & $-0.238 * * *$ & $1.175^{* * *}$ & $-0.226 * * *$ & $-1.997 * * *$ & $0.025^{* *}$ & -0.023 \\
\hline & $(0.043)$ & $(0.524)$ & $(0.047)$ & $(0.398)$ & $(0.027)$ & $(0.448)$ & $(0.012)$ & $(0.175)$ \\
\hline \multirow[t]{2}{*}{$\operatorname{lnLBR}$} & 0.032 & 0.048 & $-0.125 * * *$ & $-0.113^{* *}$ & $0.281 * * *$ & $0.266^{* * *}$ & $0.036^{*}$ & $0.035^{*}$ \\
\hline & $(0.051)$ & $(0.047)$ & $(0.045)$ & $(0.046)$ & $(0.047)$ & $(0.045)$ & $(0.019)$ & $(0.018)$ \\
\hline \multirow[t]{2}{*}{$\operatorname{lnGFCF}$} & $-0.375^{* * *}$ & $-0.367 * *$ & 0.013 & 0.019 & -0.117 & -0.124 & $-0.288 * * *$ & $-0.288 * * *$ \\
\hline & $(0.140)$ & $(0.145)$ & $(0.181)$ & $(0.172)$ & $(0.149)$ & $(0.132)$ & $(0.057)$ & $(0.058)$ \\
\hline \multirow[t]{2}{*}{ INFL_GDP } & $0.006^{* *}$ & $0.005^{* *}$ & -0.002 & -0.002 & -0.001 & -0.000 & 0.000 & 0.000 \\
\hline & $(0.002)$ & $(0.002)$ & $(0.002)$ & $(0.003)$ & $(0.002)$ & $(0.002)$ & $(0.001)$ & $(0.001)$ \\
\hline \multirow[t]{2}{*}{ lnGOVCONS } & $0.480 * * *$ & $0.559 * * *$ & $-1.348 * * *$ & $-1.286 * * *$ & $1.146 * * *$ & $1.069 * * *$ & $0.185 * * *$ & $0.183 * * *$ \\
\hline & $(0.148)$ & $(0.142)$ & $(0.150)$ & $(0.145)$ & $(0.165)$ & $(0.151)$ & $(0.052)$ & $(0.051)$ \\
\hline \multirow[t]{2}{*}{$\operatorname{lnREM}$} & $-0.139 * * *$ & $-0.237 * * *$ & $0.179 * * *$ & $0.103 * * *$ & $-0.111 * * *$ & -0.016 & -0.001 & 0.002 \\
\hline & $(0.017)$ & $(0.034)$ & $(0.017)$ & $(0.027)$ & $(0.018)$ & $(0.030)$ & $(0.007)$ & $(0.010)$ \\
\hline \multirow[t]{2}{*}{ InINTERNET } & $0.262 * * *$ & $0.246 * * *$ & 0.013 & 0.000 & $0.134 * * *$ & $0.150 * * *$ & $0.061 * * *$ & $0.061 * * *$ \\
\hline & $(0.055)$ & $(0.051)$ & $(0.057)$ & $(0.052)$ & $(0.050)$ & $(0.045)$ & $(0.017)$ & $(0.017)$ \\
\hline \multirow[t]{2}{*}{ lnKOFECGI } & 0.136 & -0.103 & -0.259 & -0.445 & $1.150 * * *$ & $1.383 * * *$ & $0.271 * *$ & $0.277 * *$ \\
\hline & $(0.368)$ & $(0.359)$ & $(0.357)$ & $(0.353)$ & $(0.284)$ & $(0.294)$ & $(0.125)$ & $(0.127)$ \\
\hline \multirow[t]{2}{*}{ ECGI_ENT } & & $-0.478 * * *$ & & $-0.372 * * *$ & & $0.466 * * *$ & & 0.012 \\
\hline & & $(0.141)$ & & (0.109) & & $(0.119)$ & & $(0.046)$ \\
\hline \multirow[t]{2}{*}{ Constant } & $5.778 * * *$ & $6.432 * * *$ & $8.873 * * *$ & $9.382 * * *$ & $-9.602 * * *$ & -10.241 **** & $2.551 * * *$ & $2.534 * * *$ \\
\hline & $(2.195)$ & $(2.200)$ & $(2.224)$ & (2.168) & $(2.066)$ & $(2.070)$ & $(0.797)$ & $(0.813)$ \\
\hline Observations & 131 & 131 & 131 & 131 & 131 & 131 & 131 & 131 \\
\hline R-squared & 0.818 & 0.834 & 0.799 & 0.810 & 0.527 & 0.583 & 0.520 & 0.520 \\
\hline
\end{tabular}

Robust standard errors in parentheses; *** $\mathrm{p}<0.01, * * \mathrm{p}<0.05,{ }^{*} \mathrm{p}<0.1$.

The study also offers additional findings. First, it is worth noting that the exports share variable appears to follow the theoretical prediction that an increase in exports has a positive effect on economic growth. The relevant coefficient is highly significant at 1 percent statistical level ranging from 0.756 to 0.798 in the respective linear and nonlinear models in Tables 5 and 6 (see Column 2 in each Table). Unsurprisingly, internet is very crucial for economic growth, as evident in Column (2). Specifically, if we change internet by one percent, we would expect economic growth change by about 0.282 percent. This is consistent with earlier findings in Jin and Jin (2014). The coefficient on personal remittances however is negatively significant in specification (2), suggesting a detrimental role of the same on economic growth. We are reluctant to take this outcome on face value given the well-known importance of remittances in Africa. But perhaps, the share of personal remittances is still too low to afford any positive impact on growth. Moreover, the finding is not uncommon in literature. For example, Habib and Nourin (2006) finds that there is negative relationship between migrant remittance and per-capita GDP growth in Thailand, Srilanka, India and Indonesia, although this relationship is positive in Bangladesh, Pakistan 
and Philippines. Similarly, Chami et al. (2003) observed that worker remittances have a negative impact on economic growth arguing that this is because most of the remittance income is spent on consumption goods and to build houses, purchase land or acquire jewelry. A negative relationship is notably observed between gross fixed capital formation and economic growth on the one hand and trade in services on the other can be noted from Table 5 .

Table 11. Entrepreneurship in Africa - political globalization

\begin{tabular}{|c|c|c|c|c|c|c|c|c|}
\hline & $\begin{array}{c}(1) \\
\text { GDPPC }\end{array}$ & $\begin{array}{c}(2) \\
\text { GDPPC }\end{array}$ & $\begin{array}{c}(3) \\
\text { AGRIC }\end{array}$ & $\begin{array}{c}(4) \\
\text { AGRIC }\end{array}$ & $\begin{array}{c}\text { (5) } \\
\text { MAN }\end{array}$ & $\begin{array}{c}\text { (6) } \\
\text { MAN }\end{array}$ & $\begin{array}{c}(7) \\
\text { SERV }\end{array}$ & $\begin{array}{c}(8) \\
\text { SERV }\end{array}$ \\
\hline $\operatorname{lnENT}$ & $\begin{array}{c}0.374 * * * \\
(0.038)\end{array}$ & $\begin{array}{c}0.086 \\
(0.549)\end{array}$ & $\begin{array}{c}-0.254 * * * \\
(0.032)\end{array}$ & $\begin{array}{l}-1.007 \\
(0.829)\end{array}$ & $\begin{array}{c}-0.140 * * * \\
(0.029)\end{array}$ & $\begin{array}{c}1.834 * * \\
(0.904)\end{array}$ & $\begin{array}{c}0.050^{* * * *} \\
(0.012)\end{array}$ & $\begin{array}{c}0.839 * * * \\
(0.314)\end{array}$ \\
\hline $\operatorname{lnGFCF}$ & $\begin{array}{l}-0.131 \\
(0.107)\end{array}$ & $\begin{array}{l}-0.102 \\
(0.117)\end{array}$ & $\begin{array}{l}-0.091 \\
(0.157)\end{array}$ & $\begin{array}{l}-0.015 \\
(0.191)\end{array}$ & $\begin{array}{l}-0.239 \\
(0.154)\end{array}$ & $\begin{array}{c}-0.439 * * * \\
(0.142)\end{array}$ & $\begin{array}{c}-0.316^{* * *} \\
(0.062)\end{array}$ & $\begin{array}{c}-0.396 * * * \\
(0.071)\end{array}$ \\
\hline $\operatorname{lnEXPORT}$ & $\begin{array}{c}0.815 * * * \\
(0.094)\end{array}$ & $\begin{array}{c}0.838 * * * \\
(0.111)\end{array}$ & $\begin{array}{c}-0.646 * * * \\
(0.108)\end{array}$ & $\begin{array}{c}-0.586 * * * \\
(0.129)\end{array}$ & $\begin{array}{c}0.386 * * * \\
(0.098)\end{array}$ & $\begin{array}{l}0.230^{*} \\
(0.116)\end{array}$ & $\begin{array}{l}-0.003 \\
(0.045)\end{array}$ & $\begin{array}{l}-0.066 \\
(0.051)\end{array}$ \\
\hline InTRADE_SER & $\begin{array}{c}-0.387 * * * \\
(0.086)\end{array}$ & $\begin{array}{c}-0.399 * * * \\
(0.086)\end{array}$ & $\begin{array}{c}0.438 * * * \\
(0.066)\end{array}$ & $\begin{array}{c}0.407 * * * \\
(0.078)\end{array}$ & $\begin{array}{c}0.061 \\
(0.091)\end{array}$ & $\begin{array}{c}0.142 \\
(0.092)\end{array}$ & $\begin{array}{c}0.068^{* *} \\
(0.028)\end{array}$ & $\begin{array}{c}0.101 * * * \\
(0.029)\end{array}$ \\
\hline INFL_GDP & $\begin{array}{c}0.001 \\
(0.002)\end{array}$ & $\begin{array}{c}0.001 \\
(0.002)\end{array}$ & $\begin{array}{c}0.001 \\
(0.002)\end{array}$ & $\begin{array}{c}0.001 \\
(0.002)\end{array}$ & $\begin{array}{l}-0.000 \\
(0.003)\end{array}$ & $\begin{array}{c}0.000 \\
(0.002)\end{array}$ & $\begin{array}{c}0.001 \\
(0.001)\end{array}$ & $\begin{array}{c}0.001 \\
(0.001)\end{array}$ \\
\hline lnGOVCONS & $\begin{array}{c}0.195 \\
(0.134)\end{array}$ & $\begin{array}{c}0.154 \\
(0.159)\end{array}$ & $\begin{array}{c}-0.937 * * * \\
(0.131)\end{array}$ & $\begin{array}{c}-1.045^{* * *} \\
(0.174)\end{array}$ & $\begin{array}{c}0.887 * * * \\
(0.160)\end{array}$ & $\begin{array}{c}1.170 * * * \\
(0.205)\end{array}$ & $\begin{array}{c}0.204 * * * \\
(0.053)\end{array}$ & $\begin{array}{c}0.317 \text { *** } \\
(0.080)\end{array}$ \\
\hline $\operatorname{lnREM}$ & $\begin{array}{c}-0.108^{* * * *} \\
(0.019)\end{array}$ & $\begin{array}{c}-0.107 * * * \\
(0.019)\end{array}$ & $\begin{array}{c}0.141 * * * \\
(0.019)\end{array}$ & $\begin{array}{c}0.144 * * * \\
(0.020)\end{array}$ & $\begin{array}{c}-0.078 * * * \\
(0.020)\end{array}$ & $\begin{array}{c}-0.085^{* * *} \\
(0.022)\end{array}$ & $\begin{array}{l}-0.001 \\
(0.008)\end{array}$ & $\begin{array}{l}-0.004 \\
(0.009)\end{array}$ \\
\hline InINTERNET & $\begin{array}{c}0.156 * * * \\
(0.048)\end{array}$ & $\begin{array}{c}0.165^{* * * *} \\
(0.052)\end{array}$ & $\begin{array}{l}-0.006 \\
(0.049)\end{array}$ & $\begin{array}{c}0.017 \\
(0.057)\end{array}$ & $\begin{array}{l}0.099 * \\
(0.057)\end{array}$ & $\begin{array}{c}0.039 \\
(0.067)\end{array}$ & $\begin{array}{c}0.042^{* *} \\
(0.018)\end{array}$ & $\begin{array}{c}0.018 \\
(0.022)\end{array}$ \\
\hline $\operatorname{lnKOFPOGI}$ & $\begin{array}{c}0.817 * * * \\
(0.165)\end{array}$ & $\begin{array}{c}0.739 * * * \\
(0.231)\end{array}$ & $\begin{array}{l}-0.247 \\
(0.185)\end{array}$ & $\begin{array}{l}-0.450 \\
(0.354)\end{array}$ & $\begin{array}{c}1.313 * * * \\
(0.250)\end{array}$ & $\begin{array}{c}1.845 * * * \\
(0.448)\end{array}$ & $\begin{array}{c}0.282^{* * *} \\
(0.070)\end{array}$ & $\begin{array}{c}0.495 * * * \\
(0.129)\end{array}$ \\
\hline POGI_ENT & & $\begin{array}{c}0.069 \\
(0.130)\end{array}$ & & $\begin{array}{c}0.180 \\
(0.196)\end{array}$ & & $\begin{array}{c}-0.471 * * \\
(0.213)\end{array}$ & & $\begin{array}{c}-0.188^{* *} \\
(0.074)\end{array}$ \\
\hline Constant & $\begin{array}{l}1.925^{*} \\
(1.000)\end{array}$ & $\begin{array}{l}2.209 * \\
(1.147)\end{array}$ & $\begin{array}{c}7.252^{* * *} \\
(1.074)\end{array}$ & $\begin{array}{c}7.994 * * * \\
(1.526)\end{array}$ & $\begin{array}{c}-6.670^{* * *} \\
(1.518)\end{array}$ & $\begin{array}{c}-8.614 * * * \\
(2.120)\end{array}$ & $\begin{array}{c}2.879 * * * \\
(0.442)\end{array}$ & $\begin{array}{c}2.101 * * * \\
(0.591)\end{array}$ \\
\hline Observations & 129 & 129 & 129 & 129 & 129 & 129 & 129 & 129 \\
\hline R-squared & 0.896 & 0.896 & 0.850 & 0.851 & 0.534 & 0.567 & 0.544 & 0.580 \\
\hline
\end{tabular}

Robust standard errors in parentheses; *** $\mathrm{p}<0.01, * * \mathrm{p}<0.05, * \mathrm{p}<0.1$.

At the sectoral level, an increase in the labor force appears to be detrimental to the Agriculture share. A change in the labor force by 1 percent would result into about 0.076 percent change in the Agriculture share of GDP. This might not be surprising since the sector to be concentrated and any increase leads to further levels in subsistence rather than in agricultural products for sale to the market, and therefore not contributory to GDP. Yet the labor force addition to the sector might overly be unskilled leading to low productivity of the sector and thus her contribution to the overall GDP. On the other hand, an increase in labor force by one percent would increase the manufacturing share in GDP by about 0.268 percent. The increase in the export of goods and services however is important for the manufacturing sector while unhelpful in the agriculture sector. Unsurprisingly, trade in services significantly contributes to the primary, secondary and tertiary sectors. Specifically, a 1 percent change in trade in services would be expected to result into 0.371 percent, 0.253 percent and 0.072 percent in agriculture, manufacturing and services sector respectively, as evident in Columns (4), (6), and (8) of Table 5. The greatest and most significant impact is observed in the agriculture sector, perhaps attributable to its relative larger size in terms of employment. An important note still is that while the personal remittances appear beneficial to the agriculture sector and potentially for the services sector, the relevant coefficient in the manufacturing sector model exhibits a significantly adverse effect. In concrete terms, a change in personal remittances by 1 percent would expectedly lead to a reduction of about 0.078 percent in the manufacturing sector whereas, a similar change would tantamount to about 0.143 percent improvement in the agriculture sector, almost twice as much as in the manufacturing sector. Perhaps, the result points to the investment motive of remittances, where migrants send back money to invest in the agriculture sector (Nnyanzi, 2015).

Government expenditure on the other hand exhibits variations in its effect on sector-wide GDP. While the 
agriculture sector is detrimentally influenced to the tune of about 0.979 percent in response to a 1 percent change in government final consumption expenditure, the observed impact on the manufacturing and services sectors is respectively 0.964 percent and 0.188 percent as evident in Columns (6) and (8). As such, the impact is by magnitude bigger in the secondary than in the tertiary sectors. By implication, government spending can be an effective tool in enhancing the manufacturing sector as well as the services sector, perhaps by means of grants and subsidies to the sector. The other finding worth of notice is the internet effect on both of the latter sectors. A 1 percent change in the number of individuals using the Internet (\% of population) is expected to result into an increase of 0.119 percent and 0.064 percent in the manufacturing and services sector respectively. Still here, the former attracts a larger impact in terms of magnitude, although the effect is most significant in the latter sector. Surprisingly, an increase in gross fixed capital formation appears deleterious in the services sector.

\section{Summary and Concluding Remarks}

We set out to examine the effect of entrepreneurship on sectoral growth and the mechanisms that drive this linkage, if any. First the direct effect of entrepreneurship on each of the three sectors, viz., manufacturing, services and agriculture sector, was analyzed. For comparison purposes however, entrepreneurial effects on aggregate economic growth was also examined. Secondly, the paper undertook to establish the channels via which the observed effect takes place. In particular, we analyzed three possible avenues: the financial development channel, the globalization channel and the governance or institutional environment channel. While the financial development channel was analyzed from two perspectives, viz., the financial depth and financial sophistication, we investigated the globalization channel by focusing on the economic globalization and political globalization. It was also important to determine the extent to which the results were dependent on the level of development.

There are several key findings worth of notice from our study. First, we find ample evidence in support of our hypothesis that entrepreneurship is important for economic growth. However, the direction of the impact differs from one sector to another. Second, while overall, entrepreneurship is observed crucial in invigorating aggregate GDP per capita and the services sector, data shows that the effect on the entrepreneurial effect on the agriculture and manufacturing sectors is significantly negative. Further analysis uncovers that financial development, institutions and globalization are key moderating factors in the relationship between entrepreneurship and growth. Additional findings point to the importance of internet in enhancing aggregate GDP and sector-wide GDP growth. Government expenditure on the other hand appears to have benefited only the manufacturing and services sectors whereas trade in services is a very critical driver of the all the three sectors analyzed just as personal remittances matter significantly for agriculture sector development. It is important to observe too that the export ratio to GDP is helpful in facilitating aggregate GDP per capita and the manufacturing sector.

In light of the above findings, the study advocates for policies that promote entrepreneurial activities as an avenue to achieve aggregate as well as sector-wide growth especially in the services sector. Investment in entrepreneurial skills is likely to stimulate economic performance. Additionally, the strategies to advance the financial systems in terms of depth and sophistication would be handy in boosting entrepreneurship in the agriculture and manufacturing sectors. Besides, we equally recommend further improvement in the institutional quality and political stability in particular, as well as pro-globalization strategies. Any endeavors to promote access and use of internet as well as trade in services would be a step in the right direction.

Future research would be undertaken on a larger sample from Africa for an extended period of time once data becomes available. In any case, the current study is not short of relevancy as it has endeavored to take into consideration the possible weaknesses in the analysis using the best available techniques. Perhaps one other possibility is to use micro-data to carry out a similar analysis. Our focus was however limited to macro-data in order to benefit from the well-known advantages of panel analysis in a macro environment.

\section{References}

Acs, Z. J., \& Szerb, L. (2008). A Complex Entrepreneurship Context Index. Unpublished working paper.

Ács, Z. J., Szerb, L., \& Lloyd, A. (2017). The Global Entrepreneurship Index. The Global Entrepreneurship and Development Institute, Washington, D.C., USA.

Aghion, P., \& Howitt, P. (1992). A Model of Growth through Creative Destruction. Econometrica, 60, 323-51. https://doi.org/10.2307/2951599

Akpor-Robaro, M. O. M. (2012). The Impact of Globalization on Entrepreneurship Development in Developing Economies: A Theoretical Analysis of the Nigerian Experience in the Manufacturing Industry. Management Science and Engineering, 6(2). 
Anderson, T. W., \& Cheng, H. (1981). Estimation of Dynamic Models with Error Components. Journal of the American Statistical Association, 76, 598-606. https://doi.org/10.1080/01621459.1981.10477691

Aparicio, S. (2017). Linking institutions, entrepreneurship and economic development: An International study. Doctoral Thesis, Universty Autonoma de Barcelona, International Doctorate in Entrepreneurship and Management, Bellaterra (Cerdanyola del Valles), June 2017.

Aparicio, S., Urbano, D., \& Audretsch, D. (2016) Institutional factors, opportunity entrepreneurship and economic growth: Panel data evidence. Technological Forecasting and Social Change, 102, 45-61. https://doi.org/10.1016/j.techfore.2015.04.006

Arellano, M., \& Bover, O. (1995). Another Look at the Instrumental Variables Estimation of Error-Components Models. Journal of Econometrics, 68, 29-51. https://doi.org/10.1016/0304-4076(94)01642-D

Aubry, M., Bonnet, J., \& Renou-Maissant, P. (2015). Entrepreneurship and the business cycle: the "Schumpeter" effect versus the "refugee" effect—a French appraisal based on regional data. The Annals of Regional Science, 54(1), 23-55. https://doi.org/10.1007/s00168-014-0645-x

Audretsch, D. B., \& Keilbach, M. (2008). Resolving the knowledge paradox: Knowledge spillover entrepreneurship and economic growth. Research Policy, 37(10), 1697-1705. https://doi.org/10.1016/j.respol.2008.08.008

Audretsch, D., Keilback, M., \& Lehmann, E. (2006). Entrepreneurship and Economic Growth. Oxford University Press, Inc, New York. https://doi.org/10.1093/acprof:oso/9780195183511.001.0001

Bassanini, A., Scarpetta, S., \& Hemmings, P. (2001). Economic Growth: The Role of Policies and Institutions. Panel Data Evidence from OECD Countries. OECD Economics Department, Working Papers No. 283.

Bathelt, H. (2001). Regional competence and economic recovery: Divergent growth paths in Boston's high technology economy. Entrepreneurship \& Regional Development, 13(4), 287-314. https://doi.org/10.1080/08985620110067502

Bjørnskov, C., \& Foss, N. J. (2013). How strategic entrepreneurship and the institutional context drive economic growth. Strategic Entrepreneurship Journal, 7, 50-69. https://doi.org/10.1002/sej.1148

Bjørnskov, C., \& Foss, N. J. (2016). Institutions, entrepreneurship, and economic growth: What do we know and what do we still need to know? The Academy of Management Perspectives, 30(3), 292-315. https://doi.org/10.5465/amp.2015.0135

Blanchflower, G. (2000). Self-employment in OECD countries. Labor Economics, 7, 471-505. https://doi.org/10.1016/S0927-5371(00)00011-7

Blundell, R., \& Bond, S. (1998). Initial Conditions and Moment Restrictions in Dynamic Panel Data Models. Journal of Econometrics, 87, 115-143. https://doi.org/10.1016/S0304-4076(98)00009-8

Bosma, N., Stam, E., \& Wennekers, S. (2011). Intrapreneurship versus independent entrepreneurship: A cross-national analysis of individual entrepreneurial behaviour. Tjalling Koopmans Institute Working Paper 11-04. Utrecht: Utrecht University School of Economics.

Bruns, K., Bosma, N., Sanders, M., \& Schramm, M. (2015). Entrepreneurship, institutions and growth in European regions: A uniform mechanism? Utrecht School of Economics Tjalling C. Koopmans Research Institute Discussion Paper Series 15-02.

Bunyasrie, V. (2010). The Role of Entrepreneurship on Economic Growth. Executive Journal, 149-156.

Carree, M. A., \& Thurik, A. R. (2003). The Impact of Entrepreneurship on Economic Growth. In Z. J. Acs, \& D. B. Audretsch (Eds.), Handbook of Entrepreneurship Research (pp. 437-471). Boston: Kluwer Academic Publishers.

Carree, M., van Stel, A., Thurik, R., \& Wennekers, S. (2002). Economic Development and Business Ownership: An Analysis Using Data of 23 OECD Countries in the Period 1976-1996. Small Business Economics, 19, 271-290. https://doi.org/10.1023/A:1019604426387

Chami, R., Connel, F. K., \& Samir, J. (2003). Are immigrants' remittances flows a source of capital for development? IMF Working Paper, WP/03/189.

Chang, E. P. (2011). Exploring the effects of entrepreneurship capital on the private economic impact of American counties. United States Association for Small Business and Entrepreneurship (USASBE).

Chenaa, T. A., \& Kimengsi, J. N. (2016). Investigating the role of agriculture, industry and foreign direct 
Investment in Cameroon's economic growth. Greener Journal of Social Sciences, 6(1), 010-018. https://doi.org/10.15580/GJSS.2016.1.090915129

Doran, J., McCarthy, N., \& O'Connor, M. (2018). The role of entrepreneurship in stimulating economic growth in developed and developing countries. Cogent Economics \& Finance, 6(1). https://doi.org/10.1080/23322039.2018.1442093

Eklund, J. E., \& Sund, L. G. (2014). Corporate Governance, Entrepreneurship and Economic Development. Swedish Entrepreneurship Forum. Working Papers Series, WORKING PAPER 2014:28.

Elkan, W. (1988). Entrepreneurs and entrepreneurship in Africa (English). The World Bank Research Observer, 3(2), 171-188. https://doi.org/10.1093/wbro/3.2.171

Fal, M. (2013). Accelerating Entrepreneurship in Africa. Innovations, 8(3/4), 149-168. https://doi.org/10.1162/INOV_a_00193

Fritsch, M. (2013). New business formation and regional development - a survey and assessment of the evidence. Foundations and Trends in Entrepreneurship, 9, 249-364. https://doi.org/10.1561/0300000043

Greene, W. H. (2011). Econometric Analysis (7th ed.). Pearson Education, New York University.

Habib, M. R., \& Nourin, S. (2006). Remittances and real investment: An appraisal on South and South East Asian economies. Faculty of Economics, Chulalongkorn University, Asian Institute of Technology, Bangkok. Retrieved from http://www.doaj.org/doaj?func=abstract\&id=243088

Henrekson, M. (2002). Entrepreneurship - A Weak Link in the Mature Welfare State. SSE/EFI Working paper No 518, Stockholm School of Economics, Stockholm.

Herrington. M., \& Kelley. D. (2013). Global Entrepreneurship Monitor Sub-Saharan African Regional Report. Retrieved from http://www.gemconsortium.org/docs/2009/gem-2012-sub-saharan-africa-regional-report

Jin, L., \& Jin, J. C. (2014). Internet Education and Economic Growth: Evidence from Cross-Country Regressions. Economies, 2, 78-94. https://doi.org/10.3390/economies2010078

Judson, R. A., \& Owen. A. L. (1999). Estimating Dynamic Panel Data Models: A Guide for Macroeconomists. Economic Letters, 65, 9-15. https://doi.org/10.1016/S0165-1765(99)00130-5

Karlson, C., Fris, C., \& Paulson, T. (2004). Relating Entrepreneurship to Economic Growth. Working Paper No. 13, Economics and Institutions of Innovation Royal Institute of Technology, Centre of Excellence for Science and Innovation Studies: Stockholm. Retrieved July 10, 2018 from http://www.ideas.repec.org/p/hhs/ccsisp/0013.html

Koo, J., \& Kim, T. E. (2009). When R\&D matters for regional growth: A tripod approach. Papers in Regional Science, 88(4). https://doi.org/10.1111/j.1435-5957.2009.00261.x

Kritikos, A. S. (2014). Entrepreneurs and their impact on jobs and economic growth. IZA World of Labor. https://doi.org/10.15185/izawol.8

Leke, A., \& Barton, D. (2016). 3 reasons things are looking up for African economies. Retrieved October 6, 2018, from http://www.weforum.org/agenda/2016/05/what-s-the-future-of-economic-growth-inafrica

Linan, F., \& Fernandez-Serrano, J. (2014). National culture, entrepreneurship and economic development: Different patterns across the European Union. Small Business Economics, 42(4), 685-701. https://doi.org/10.1007/s11187-013-9520-x

Low, S. A., \& Isserman, A. M. (2015). Where Are the Innovative Entrepreneurs ? Identifying Innovative Industries and Measuring Innovative Entrepreneurship. International Regional Science Review, 38(2), 171-201. https://doi.org/10.1177/0160017613484926

Lucas, R. E. (1988). On the Mechanics of Economic Development. Journal of Monetary Economics, 22(1), 3-42. https://doi.org/10.1016/0304-3932(88)90168-7

Lundin, J. (2015). Entrepreneurship and Economic Growth: Evidence from GEM Data. Master's thesis in Economics, Lund University, Department of Economics, School of Economics and Management.

Maddala, G. S. (2001). Introduction to Econometrics (3rd Ed.). New York: Wiley.

Nickell, S. J. (1981). Biases in Dynamic Models with Fixed Effects. Econometrica, 49, 1417-1426. https://doi.org/10.2307/1911408

Nnyanzi, J. B. (2015). What drives International Remittances to Africa: Altruism, Self-interest or the institutional 
environment? African Journal of Economic and Management Studies, 7(3), 397-418. https://doi.org/10.1108/AJEMS-07-2013-0067

Nyström, K. (2007). The institutions of economic freedom and entrepreneurship: Evidence from panel data. Public Choice, 136, 269-282. https://doi.org/10.1007/s11127-008-9295-9

Omoruyi, E. M., Olamide, K. S., Gomolemo, G., \& Donath, O. A. (2017). Entrepreneurship and Economic Growth: Does Entrepreneurship Bolster Economic Expansion in Africa? J Socialomics, 6(4), 219.

Rae, D. (2007). Entrepreneurship - from opportunity to action. London: Palgrave MacMillan.

Raoofi, A., Afghah, M., \& Hoshyar, S. (2014). A study on the effect of entrepreneurship on economic growth.

Reynolds, P., Bosma, N., Autio, E., Hunt, S., De Bono, N., Servais, I., Lopez-Garcia, P., \& Chin, N. (2005). Global entrepreneurship monitor: Data collection design and implementation 1998-2003. Small Business Economics, 24, 205-231. https://doi.org/10.1007/s11187-005-1980-1

Rodrigues, D. R. (2018). The impact of (opportunity and necessity) entrepreneurship on economic growth: Does human capital matter? Masters Dissertation, Faculty of Economics, University of Porto, June 2018.

Romer, P. M. (1986). Increasing return and long-run growth. Journal of Political Economy, 94, 1002-1037. https://doi.org/10.1086/261420

Romer, P. M. (1990). Endogenous technological change. Journal of Political Economy, 98, 71-101. https://doi.org/10.1086/261725

Salgado-Banda, H. (2005). Entrepreneurship and Economic Growth: An Empirical Analysis. DEGIT Conference Papers. Dirección General de Investigación Económica. Banco de México.

Schumpeter, J. A. (1904). The Theory of Economic Development. Cambridge. Mass: Harvard University Press.

Schumpeter, J. A. (1912). The Theory of Economic Developmen (10th ed.). Transaction Publishers, New Brunswick, New Jersey.

Schumpeter, J. A. (1934). The Theory of Economic growth. Cambridge: Harvard University Press.

Schumpeter, J. A. (1942). Capitalism, Socialism and Democracy (3rd ed.). London: George Allen and Unwin, 1976.

Scott, C. E. (1986). Why More Women Are Becoming Entrepreneurs. Journal of Small Business Management, 24(4), 37-44.

Shepherd, D. A., \& Patzelt, H. (2015). The "heart" of entrepreneurship: The impact of entrepreneurial action on health and health on entrepreneurial action. Journal of Business Venturing Insights, 4, 22-29. https://doi.org/10.1016/j.jbvi.2015.08.001

Smith, D. (2010). The Role of Entrepreneurship in Economic Growth. Undergraduate Economic Review, 6(1). Retrieved from http://digitalcommons.iwu.edu/uer/vol6/iss1/7

Solow, R. M. (1956). A Contribution to the Theory of Economic growth. Quarterly Journal of Economics, 70, 65-94. https://doi.org/10.2307/1884513

Stam, E. (2008). Entrepreneurship and Innovation Policy. In B. Nooteboom, \& E. Stam (Eds.), Micro-Foundations for Innovation Policy. Amsterdam: Amsterdam University Press and Chicago: Chicago University Press. https://doi.org/10.2139/ssrn.1115262

Stam, E., \& Stel, A. (2009). Types of entrepreneurship and economic growth. United Nations University, Research Paper $N^{\circ}$ 2009, 47, 1-16.

Szerb, L. (2008). The Examination of the Level of Entrepreneurship in Eight Central Eastern European Countries. MEB 2008 - 6th International Conference on Management, Enterprise and Benchmarking, May 30-31, 2008, Budapest, Hungary

Tech, K., \& Latha, K. L. (2012). Growth of Small Scale Entrepreneurship: A Case Study of Nellore District. Int. Journal of Economics and Management, 6(1), 98-114.

Uchehara, F. O. (2016). Effect of Entrepreneurship Growth on Infrastructure Development in Emerging Economies. International Journal of Scientific Research and Management, 4(5). https://doi.org/10.18535/ijsrm/v4i5.09

Uchenna, O. L., Modebe, N. J., Adedayo, E. O., \& Evbuomwan, G. O. (2010). Effect of External Debt on Economic Growth: Evidence from Nigeria. Sustainable Economic Growth, Education Excellence, and 
Innovation Management through Vision 2020.

Urbano, D., \& Aparicio, S. (2016). Entrepreneurship capital types and economic growth: International evidence. Technological Forecasting and Social Change, 102, 34-44. https://doi.org/10.1016/j.techfore.2015.02.018

Valliere D. and Peterson R., 2009. Entrepreneurship and Economic Growth: Evidence from emerging and developed countries. Entrepreneurship and Regional Development, Vol. 21, Nos. 5-6, September-November 2009, 459-480. https://doi.org/10.1080/08985620802332723

van Stel, A., Carree, M., \& Thurik, R (2005). The effect of entrepreneurial activity on national economic growth. Small Business Economics, 23, 311-321. https://doi.org/10.1007/s11187-005-1996-6

Vinig, T., \& Kluijver, J. de (2007). Does Globalization Impact Entrepreneurship? Comparative Study of Country Level Indicators. University of Amsterdam, Netherlands. Sprouts: Working Papers on Information Systems, 7(8). https://doi.org/10.2139/ssrn.1020565

Von Graevenitza, G., Harhoffac, D., \& Weberb, R. (20100). The effects of entrepreneurship education. Journal of Economic Behavior \& Organization, 76(1), 90-112. https://doi.org/10.1016/j.jebo.2010.02.015

Wennekers, S., van Stel, A., Thurik, R., \& Reynolds, P. (2005). Nascent Entrepreneurship and the Level of Economic Development. Small Business $\quad$ Economics, 293-309. https://doi.org/10.1007/s11187-005-1994-8

Wong, P. K., Ho, Y. P., \& Autio, E. (2005). Entrepreneurship, Innovation and Economic Growth: Evidence from GEM data. Small Business Economics, 24, 335-350. https://doi.org/10.1007/s11187-005-2000-1

Yu, T. F. L. (1998). Adaptive Entrepreneurship and the Economic Development of Hong Kong. World Development, 26, 897-911. https://doi.org/10.1016/S0305-750X(98)00013-8

\section{Copyrights}

Copyright for this article is retained by the author(s), with first publication rights granted to the journal.

This is an open-access article distributed under the terms and conditions of the Creative Commons Attribution license (http://creativecommons.org/licenses/by/4.0/). 